\title{
Do Loyalty Programs Really Enhance Behavioral Loyalty? An Empirical Analysis Accounting for Self-Selecting Members
}

\author{
Jorna Leenheer, Harald J. van Heerde, \\ Tammo H.A. Bijmolt and Ale Smidts
}

\begin{tabular}{|l|l|}
\hline \multicolumn{2}{|l|}{ ERIM REPORT SERIES RESEARCH IN MANAGEMENT } \\
\hline ERIM Report Series reference number & ERS-2006-076-MKT \\
\hline Publication & November 2006 \\
\hline Number of pages & 53 \\
\hline Persistent paper URL & \\
\hline Email address corresponding author & j.leenheer@seo.nl \\
\hline Address & Erasmus Research Institute of Management (ERIM) \\
& RSM Erasmus University / Erasmus School of Economics \\
& Erasmus Universiteit Rotterdam \\
& P.O.Box 1738 \\
& 3000 DR Rotterdam, The Netherlands \\
& Phone: $\quad+31104081182$ \\
& Fax: $\quad+31104089640$ \\
& Email: info@erim.eur.nl \\
& Internet: $\quad$ www.erim.eur.nl \\
\hline
\end{tabular}

Bibliographic data and classifications of all the ERIM reports are also available on the ERIM website: www.erim.eur.nl 


\section{ERASMUS RESEARCH INSTITUTE OF MANAGEMENT}

\section{REPORT SERIES}

\section{RESEARCH IN MANAGEMENT}

\begin{tabular}{|l|l|}
\hline ABSTRACT AND KEYWORDS \\
\hline Abstract & \begin{tabular}{l} 
One of the pressing issues in marketing is whether loyalty programs really enhance behavioral \\
loyalty. Loyalty program members may have a much higher share-of-wallet at the firm with the \\
loyalty program than non-members have, but this does not necessarily imply that loyalty \\
programs are effective. Loyal customers may select themselves to become members in order to \\
benefit from the program. Since this implies that program membership is endogenous, we \\
estimate models for both the membership decision (using instrumental variables) and for the \\
effect of membership on share-of-wallet, our measure of behavioral loyalty. We use panel data \\
from a representative sample of Dutch households who report their loyalty program \\
memberships for all seven loyalty programs in grocery retailing as well as their expenditures at \\
each of the 20 major supermarket chains. We find a small positive yet significant effect of loyalty \\
program membership on share-of-wallet. This effect is seven times smaller than is suggested by \\
a naïve model that ignores the endogeneity of program membership. The predictive validity of \\
the proposed model is much better than for the naïve model. Our results show that creating \\
loyalty program membership is a crucial step to enhance share-of-wallet, and we provide \\
guidelines how to achieve this. \\
Loyalty programs, Grocery retailing, Endogeneity, Tobit-II model, Attraction models \\
The ERIM Report Series is distributed through the following platforms: \\
\hline Free Keywords
\end{tabular} \mid $\begin{array}{l}\text { Academic Repository at Erasmus University (DEAR), DEAR ERIM Series Portal } \\
\text { Social Science Research Network (SSRN), SSRN ERIM Series Webpage } \\
\text { Research Papers in Economics (REPEC), REPEC ERIM Series Webpage } \\
\text { Availability } \\
\text { The electronic versions of the papers in the ERIM report Series contain bibliographic metadata } \\
\text { Library of Congress Classification, (LCC) LCC Webpage } \\
\text { Journal of Economic Literature, (JEL), JEL Webpage } \\
\text { ACM Computing Classification System CCS Webpage } \\
\text { Inspec Classification scheme (ICS), ICS Webpage }\end{array}$ \\
\hline
\end{tabular}




\title{
Do Loyalty Programs Really Enhance Behavioral Loyalty? An Empirical Analysis Accounting for Self-Selecting Members
}

\author{
Jorna Leenheer, Harald J. van Heerde, Tammo H.A. Bijmolt, Ale Smidts
}

November 01, 2006

Jorna Leenheer is Researcher at SEO Economic Research, University of Amsterdam, Roeterstraat 29, 1018 WB Amsterdam, the Netherlands. Tel: +31-20-5251678. Fax: +31-205251686. E-mail: j.leenheer@seo.nl. Harald J. van Heerde is Professor of Marketing, Waikato Management School, Hamilton, New Zealand. Tammo H.A. Bijmolt is Professor of Marketing Research, University of Groningen, the Netherlands. Ale Smidts is Professor of Marketing Research, Erasmus University Rotterdam, the Netherlands. 


\title{
Do Loyalty Programs Really Enhance Behavioral Loyalty?
}

\section{An Empirical Analysis Accounting for Self-Selecting Members}

\begin{abstract}
One of the pressing issues in marketing is whether loyalty programs really enhance behavioral loyalty. Loyalty program members may have a much higher share-of-wallet at the firm with the loyalty program than non-members have, but this does not necessarily imply that loyalty programs are effective. Loyal customers may select themselves to become members in order to benefit from the program. Since this implies that program membership is endogenous, we estimate models for both the membership decision (using instrumental variables) and for the effect of membership on share-of-wallet, our measure of behavioral loyalty. We use panel data from a representative sample of Dutch households who report their loyalty program memberships for all seven loyalty programs in grocery retailing as well as their expenditures at each of the 20 major supermarket chains. We find a small positive yet significant effect of loyalty program membership on share-of-wallet. This effect is seven times smaller than is suggested by a naïve model that ignores the endogeneity of program membership. The predictive validity of the proposed model is much better than for the naïve model. Our results show that creating loyalty program membership is a crucial step to enhance share-of-wallet, and we provide guidelines how to achieve this.
\end{abstract}

Keywords: loyalty programs, grocery retailing, endogeneity, tobit-II model, attraction models 


\section{INTRODUCTION}

The effect of loyalty programs on loyalty is a topic of debate. Most loyalty programs do not turn all disloyal customers into loyals or make customers exclusively loyal. This does not mean that a loyalty program cannot be a useful tool. As expressed by Koslowsky (1999): "While none of these programs result in a perfect world, each can generate that little extra that can provide the retail marketer with potential tactical weapons". A supermarket manager describes the added value of its loyalty program as follows: "You don't have 100 percent of a share of a customer's wallet. Customers shop about five times a month. Maybe you'll get three of those trips and the competition gets two. The loyalty program eliminates at least one shopping trip you weren't getting and creates an additional shopping trip to your store"

(Cioletti, 2001). Hence, it is important to correctly quantify that 'little extra' that a loyalty program can offer to a retailer.

Recently, many retail companies have introduced loyalty programs to enhance customer loyalty (Kumar \& Reinartz, 2005). Loyalty programs are currently available in many industries, such as supermarkets, gasoline stations, and clothing stores (Leenheer \& Bijmolt, 2003; Lewis, 1997). Loyalty programs provide members with benefits such as discounts and saving rewards, which make these programs popular among consumers (Liebermann, 1999). In the United States, almost $80 \%$ of all households have at least one supermarket loyalty card, and in Canada this is even 90\% (ACNielsen, Consumer Insight, 2002).

Extant empirical research provides mixed evidence of loyalty program effectiveness. Some studies found positive effects of retail loyalty programs on purchase behavior (Bell \& Lal, 2003; Lewis, 2004; Taylor \& Neslin, 2005), whereas others provide evidence of loyalty programs that do not generate any effects (Mägi, 2003; DeWulf, Odekerken-Schröder, \& Iacobucci, 2001; Sharp \& Sharp, 1997). This ambiguity may relate at least partly to the fact 
that methodological limitations hinder proper assessment of loyalty programs effects. A potential problem is that customers who are already loyal may have a higher likelihood to enroll into the program, leading to an overestimation of the loyalty program effect. In other words, expenditure differences between members and non-members (Van Heerde and Bijmolt, 2005) may be partly driven by self-selection of the most loyal customers into the loyalty program. To illustrate our point, we show in Table 1 descriptive statistics for our empirical study on grocery loyalty programs. There are substantial differences in share-ofwallet (SOW) between members and non-members: the average share-of-wallet of members is $36 \%$, which is 29 percentage points higher than the average share-of wallet of non-members (7\%). The central question of this study is to what extent this gap is due to self-selection and to what extent loyalty programs really enhance behavioral loyalty. Existing research has ignored this self-selection or endogeneity problem, as argued by Bolton, Lemon, and Verhoef (2004). They propose that a thorough solution for this problem is needed before any conclusion can be made on loyalty program effectiveness.

[Insert Table 1 about here]

This paper aims to measure the impact of loyalty programs on customer loyalty while controlling for endogeneity due to self-selecting members by using a model with instrumental variables. We apply our model to data from a representative Dutch sample of 1909 households who report their loyalty program memberships for all seven loyalty programs in Dutch grocery retailing as well as their expenditures at each of the 20 major supermarket chains. The wide and empirical scope of the study allows us to conclude that loyalty programs really enhance behavioral loyalty, albeit seven times less than what we would conclude if we did not control for self-selecting members. This paper also aims to deepen the substantive knowledge about what determines the effectiveness of loyalty programs, as called for by Jain and Singh (2002). Though experimental research indicates that the effectiveness of loyalty 
programs depends on the program's design (Kivetz \& Simonson, 2002a; Roehm, Bolman Pullins, \& Roehm, 2002; Van Osselaer, Alba, \& Manchanda, 2003; Yi \& Jeon, 2003), there is no evidence from empirical field data to date. In this paper we study two loyalty program design elements: the discount percentage and the percentage of a household's expenditures that is redeemed as a saving program reward. Our findings suggest that these design elements do affect the decision to enroll in a program, but they do not impact the effectiveness of loyalty programs once consumers are enrolled.

The remainder of the paper is structured as follows. Section 2 develops a conceptual framework on the relation between loyalty programs and purchase behavior. Section 3 discusses the data of our empirical study, and Section 4 describes the model. A presentation of the results follows, and we conclude with a discussion.

\section{CONCEPTUAL FRAMEWORK}

\section{Customer Loyalty}

The marketing literature provides a wide range of loyalty measures (Odin, Odin, \& Valette-Florence, 2001), and their usefulness depends on the specific market and study objective. The main distinction in loyalty measures is between attitudinal loyalty and behavioral loyalty (Dick \& Basu, 1994). Since we are interested in the effects of loyalty programs on actual purchase behavior, our key dependent variable captures behavioral loyalty. In grocery retailing, purchase behavior is characterized by high buying frequency and variation in basket sizes (Kahn \& Schmittlein, 1992). Further, consumers are often regular buyers at different companies (Kahn \& McAlister, 1997), a phenomenon referred to as polygamous loyalty (Dowling \& Uncles, 1997). Given these characteristics, share-of-wallet is the most suitable measure for behavioral loyalty (Berger et al., 2002; Mägi, 2003). Share-ofwallet measures the share of category expenditures spent on purchases at a certain company, 
which integrates choice behavior and transaction sizes during a certain time period into one single measure.

\section{Effectiveness of loyalty programs: accounting for self-selecting members}

In line with previous research (e.g. Sharp \& Sharp, 1997; Yi \& Jeon, 2003), we define a loyalty program as an integrated system of marketing actions that aims to make member customers more loyal. The central question is whether loyalty program members become more loyal due to their memberships. Customers do not become loyalty program members randomly. Rather, a customer becomes a member of the loyalty program if the expected benefits are higher than the expected costs, a choice that is partly driven by the attraction of the store itself (Mauri, 2003). Because loyal customers derive the highest benefits from a loyalty program, those customers who are already loyal are most likely to participate (Bolton, Lemon, \& Verhoef, 2004). From an econometric perspective, this comes down to an endogeneity problem. The relevant issue is that in a model with share-of-wallet as the dependent variable and loyalty program membership as an independent variable, the loyalty program membership variable and the error term of the model are positively correlated. Due to this positive correlation, the influence of loyalty program membership will be overestimated (Greene, 2000, p.370; Verbeek, 2000, p.121). Although including additional observed independent variables that drive share-of-wallet (such as location or price) might mitigate the problem, this solution does not correct for unobserved independent variables (Franses, 2005).

The solution for endogeneity we follow is two-stage least squares (2SLS). We must (and do) identify variables (instruments) that influence the loyalty program membership decision of a household, but that are unrelated to the household's share-of-wallet. We first estimate a model for loyalty program membership, with the instruments and other available 
variables as independent variables. The predicted values from this model (instead of the observed loyalty program memberships) should then be imputed as an independent variable in the main model for share-of-wallet (more details are discussed later in this paper).

In Figure 1, we present our framework for studying loyalty program membership and share-of-wallet. The share-of-wallet for a store depends on its attraction compared to the attraction of competitors. We now discuss several drivers of a store's attraction.

[Figure 1 about here]

\section{Effect of Loyalty Program Membership on Store Attraction}

The central driver in this study is loyalty program membership. Loyalty programs enhance customer loyalty through several economic, psychological and sociological mechanisms. From an economic perspective, loyalty programs provide members with value in the form of rewards. A second economic driver consists of switching costs, because loyalty program members lose value if they stop purchasing from the company. The value lost consists of saving points or a purchasing track record that ensures privileges. Economicoriented research has used the switching cost argument as a rationale for the existence of loyalty programs (Kim, Shi, \& Srinivasan, 2001; Klemperer, 1987; Kopalle \& Neslin, 2003) ${ }^{1}$. Because of switching costs, a loyalty program creates a certain degree of calculative commitment or stickiness in customers' relation with the company (Johnson, Gustafsson, Andreassen, Levik, \& Cha, 2001). Calculative commitment can be defined as the extent to which consumers perceive the need to maintain a relationship, given the significant termination or switching costs associated with leaving (Geyskens, Steenkamp, Scheer, \& Kumar, 1996).

\footnotetext{
${ }^{1}$ If the collected points and privileges do not expire (as is often the case in grocery retailing), there is no switching cost to a consumer who switches temporarily to a competitor. However, if the switch is permanent, the consumer incurs the switching cost of foregoing the collected rewards and privileges, even if these do not expire.
} 
Further, several psychological drivers enhance customer loyalty. First of all, consumers appreciate rewards -- not only in an absolute sense, but also relative to other consumers (Feinberg, Krishna, \& Zhang, 2002). Knowing that you are provided with better value than others creates feelings of being a preferred or special customer, and thereby further stimulates loyal behavior. Second, loyalty program incentives can induce smart shopper feelings (Kivetz \& Simonson, 2002b), and pride about being economical (Chandon, Wansink, \& Laurent, 2000; Schindler, 1998). The effort to obtain the reward may even justify luxury consumption (Kivetz \& Simonson, 2002a). Third, existing research shows that customers overvalue the rewards they obtain, as they tend to maximize the value offered by the medium (the loyalty program), rather than the final outcome (Hsee, Yu, Zhang \& Zhang, 2003; Van Osselaer, Alba, \& Manchanda 2003). This implies that customers aim to maximize discounts and saving points, whereas it would be rational to assess the utility of the final products and rewards minus the disutility of their costs.

Loyalty programs can also have sociological effects. The need to belong to groups is a fundamental human motivation (Baumeister \& Leary, 1995), and identification with commercial organizations is intensifying due to the growing centrality of consumption and materialistic desires in society (Fournier, 1998; Muniz \& O'Guinn, 2001). Bhattacharya and Sen (2003) propose that strategies to develop customer identification are especially beneficial in industries where consumers purchase frequently, and differentiation between suppliers is low. DeWulf, Odekerken-Schröder, and Iacobucci (2001) show for relational investments in consumer-firm relationships the existence of a reciprocity norm: customers evoke obligation towards those who treat them well or provide value. In addition, customers who become members of the loyalty program are likely to identify more strongly with the company, because the membership relates them to a group of privileged customers (Bhattacharya, Rao, \& Glynn, 1995; Oliver, 1999). Hence, loyalty programs can create affective commitment, a 
generalized sense of positive regard for, and attachment to, the organization. In this way, loyalty programs not only buy, but also earn, customer loyalty (Edvardsson, Johnson, Gustafsson, \& Strandvik, 2000).

Overall, multiple drivers may create a positive effect of being a loyalty program member on the attractiveness of the store. This research does not aim to assess the relative importance of each driver, but rather aims to provide a proper empirical assessment of the overall effect. The importance of the drivers might also depend on loyalty program type (Bolton, Kannan, \& Bramlett, 2000). The focus of our research is on loyalty programs that provide predominantly economic (tangible) rewards, but enrich them with some social (intangible) rewards. Therefore, we only study the moderating impact of economic design elements, as we discuss below.

\section{The Moderating Impact of Loyalty Program Design on Loyalty Program Effectiveness}

The effectiveness of a loyalty program is likely to depend on its design (Dowling $\&$ Uncles, 1997; Jain \& Singh, 2002). An important element is how much monetary value the loyalty program gives to its members, and in which form. The key economic design elements of the loyalty program are its discount and saving features (Yi \& Jeon, 2003). The program with a discount feature gives price discounts on certain items of the assortment for loyalty program members only. In this way, a discount feature supplies member customers with immediate rewards for their purchases (Yi \& Jeon, 2003). The discount feature stimulates customers to purchase the items on promotion or to buy categories they usually buy in other stores.

A program with a saving feature gives loyalty program members saving points, dependent on the monetary amount spent at the company. A program member can redeem these points for a reward, such as a free product, after s/he has reached a saving threshold 
(see, e.g., Hoch and Drèze 1998). The saving feature stimulates customers to show loyal purchase behavior to reach certain threshold levels (Lewis, 2004), which is called the pointspressure mechanism (Taylor \& Neslin, 2005). Further, a saving feature creates switching costs (Zhang, Krishna, \& Dhar, 2000): if a consumer stops purchasing s/he loses the accumulated saving points.

The question is whether a saving feature or a discount feature is more effective. A saving feature stimulates purchases of the entire assortment and not only of specific items (as the discount feature does). Obtaining saving rewards requires considerable consumer effort, so that we expect stronger feelings of uniqueness and pride (psychological drivers). A discount has, in contrast with saving points, a direct negative effect on share-of-wallet. On the other hand, customers prefer to obtain a reward immediately instead of getting it sometime in the future (Yi \& Jeon, 2003). Further, the discount feature directly supports the supermarket's value proposition (Dowling \& Uncles, 1997). Finally, the saving feature may also have a positive effect on behavior after the reward has been redeemed (Taylor \& Neslin, 2005). In sum, both saving and discount features contain attractive aspects to consumers, so that we do not have an ex-ante expectation of differences between moderating effects of the saving and the discount features.

\section{The Moderating Impact of Household Characteristics on Loyalty Program Effectiveness}

We expect that household characteristics moderate the effects of loyalty programs on the attraction of a store. Since grocery bills tend to be higher for larger households, the absolute monetary incentive they may derive from loyalty programs is higher than for smaller households. As a result, we expect loyalty program effects to be stronger for larger households. Families with higher incomes also tend to have higher grocery bills since they may buy more luxurious products. On the other hand, they may value the monetary rewards 
from loyalty programs less than families with lower incomes. Hence, the sign of the moderating impact of household income on loyalty program effectiveness is not clear a priori.

\section{The Effects of Store and Household Variables on Store Attraction}

A store's attractiveness depends on the benefits of the attributes offered by the store. Three important store attributes are proximity to the store (distribution density), price attractiveness, and service level (Kahn \& McAlister, 1997). Extant research has found that households with different socio-demographic characteristics derive different benefits from the same store attributes, e.g. because of variation in opportunity costs (Bell \& Lattin, 1998). We therefore expect that the relationship between a store variable and attraction is moderated by household characteristics. We do not include the main effects of household variables on a store's attraction because from a theoretical perspective there is no a priori reason to expect some households to favor a particular store independent of that store's attributes. In addition, these main effects cancel out in the chosen attraction model specification (see footnote 4).

Closer average proximity (higher density of outlets of a retail company) enhances a chain's attraction, because the expected travel costs are lower. However, a high distribution density is less important if the potential benefits of visiting a store further away are higher. These expected benefits are higher for larger basket sizes, which are associated with larger households (Bell \& Lattin, 1998). For high-income households, different effects might counterbalance each other: these households have higher marginal costs of time, but the possession of cars and storage space diminish travel costs and increase basket sizes (Mittal, 1994). In sum, we expect a positive effect of distribution density on attraction that is moderated negatively by household size and undeterminably by household income.

We expect that a more attractive price and higher service levels increase a store's attractiveness. Income is expected to moderate the price attractiveness effect positively and 
the service-level effect negatively. Larger households can benefit more from a low price setting because of larger basket sizes (Bell \& Lattin, 1998), leading to a stronger effect of the attractive prices. These households may value service more because they have higher opportunity costs of time, and hence we expect that the service effect is positively moderated by household size.

\section{Drivers of Loyalty Program Membership}

When deciding whether to participate in a company's loyalty program, a customer may compare the expected benefits and costs (Bell \& Lal, 2003; Noble \& Phillips, 2004). The most direct benefits accrue from the saving reward rate (percentage of money amount spent that is reimbursed as a saving program reward) and the discount rate (percentage immediate discount on all purchases) that the program offers. The higher the saving and discount rates, the higher the likelihood of program enrollment.

We now focus on additional benefits and costs, which serve as instrumental variables in the 2SLS estimation. These benefits and costs are not related to the attraction of the specific store itself or its loyalty program, but refer to a consumer's attitude and perceptions of loyalty programs in general. ${ }^{2} \mathrm{We}$ assume that the general attitude consumers have towards loyalty programs can partly explain their memberships of specific programs, similar to what has been found for the usage of promotions and coupons (Chandon, Wansink, \& Laurent 2000; Bawa \& Shoemaker, 1987). We distinguish between perceived economic benefits (rewards) and non-economic (psychological and sociological) benefits. The more economic benefits a customer perceives to gain from loyalty programs in general, the higher the likelihood to enroll in any program. Non-economic benefits may also enhance the likelihood to enroll in a

\footnotetext{
${ }^{2}$ A paradox in statistics is that it is impossible to test for the exogeneity of instrumental variables. The only support for the exogeneity of instrumental variables is by logical reasoning. Since our instrumental variables apply for loyalty programs in general and they are not related to share-of-wallet a consumer has at a particular store, we believe we can argue convincingly that they are valid instruments in the sense of being unrelated to the error term of the share-of-wallet model.
} 
program. We note that because valid instruments need to be independent of a specific chain's error term, both types of benefits are specified toward loyalty programs in retailing in general. In the data section we provide operationalizations for these variables.

Economic costs are program membership fees (which does not apply in our setting). In addition, customers may face non-economic costs: loss of privacy. A customer who enters a loyalty program usually has to fill out a subscription form in which $\mathrm{s} / \mathrm{he}$ must provide personal data. A company can use this information in combination with purchase data (registered through the loyalty program) to target households for direct mailings or to apply micro marketing. Some customers may not be willing to provide personal information, especially if this concerns personal identifiers such as address information (Phelps, Nowak, \& Ferrell, 2000; Noble \& Philips, 2003). This reluctance is caused by consumers' need for control and a negative attitude towards direct marketing (Phelps, D'Souza, \& Nowak, 2001). Hence, some customers may perceive potential privacy infringements of loyalty programs in general as a non-economic cost, leading to a decreased likelihood of loyalty program participation. Finally, to accommodate additional benefits and costs, we use loyalty program memberships in a different industry as another instrumental variable (see Figure 1). The notion is that the more loyalty programs a consumer has been enrolled in, the more likely it is that this consumer signs up for a particular program in a different industry.

Finally, the decision to enroll may also depend on a customer's loyalty to the store, which is the essence of the self-selection problem. In order to estimate the effect of loyalty program membership on attraction consistently with 2SLS, we need to include the drivers of a store's attraction (household and store characteristics) as independent variables for the decision to become a member of a store's loyalty program. 


\section{DATA DESCRIPTION}

To assess the effects of loyalty programs on behavioral loyalty, we conduct an empirical study of the Dutch supermarket industry. This industry is an interesting market for a study of loyalty programs, because consumers make transactions in supermarkets frequently, and can easily visit several supermarkets within a relative short time-interval. We have panel data on purchase behavior of 1909 Dutch households in supermarkets during two years. The panel members provide purchase information by scanning all their supermarket receipts with a home scanner. The data cover the period July 1998 until July 2000, and were provided by GfK Panel Services Benelux. We use data for each household on yearly expenditures in the largest twenty supermarket chains; these comprise $92.8 \%$ of all supermarket sales.

We use a census of all seven loyalty programs in this industry, each of which uses loyalty cards for identification and registration. The main design elements of these programs are a discount feature and a saving feature. The discount feature provides price discounts on a varying set of items of the assortment. The saving feature provides saving points that are linearly dependent on the amount spent. Members must spend a pre-specified amount to reach the minimal redemption threshold and to exchange points for a reward (gifts or free products). The receipts report both the total discount earned with the loyalty card and the number of points saved. In addition, the loyalty programs sometimes give other rewards such as lotteries, direct mailings or member web pages. We limit the discussion of the loyalty program design to the discount and saving features, because there is no systematic variation in the other design elements.

Table 1 shows the loyalty programs and their design elements, the market shares of the supermarket chains, and some customer base characteristics. Both large and small supermarket chains have introduced loyalty programs, and some of the largest supermarkets 
in the Netherlands do not have a loyalty program. The customer base of a supermarket chain ${ }^{3}$ is defined as those households that visited the chain at least once during a certain year.

Panel households complete a yearly questionnaire in which they report on their loyalty program memberships at supermarkets. On average, $64 \%$ of a chain's customer base is loyalty program member, and this number varies between supermarket chains from $47 \%$ (Konmar) to $82 \%$ (Albert Heijn). About $88 \%$ of the panel households are members of at least one supermarket loyalty program. The duplication rate of loyalty program memberships is substantial: $33 \%$ of the panel households have two loyalty cards, $16 \%$ have three, and $4 \%$ have four or more loyalty cards. On average, a household holds 1.68 loyalty program memberships.

To operationalize the variables from Figure 1, we collected additional data, which we discuss below and summarize in Table 2.

[Insert Table 2 about here]

\section{Instrumental variables}

We operationalize the instrumental variables for loyalty program membership based on a survey held in November 2000 among the panel households. This survey, conducted by the market research company, includes eight attitude statements about loyalty programs in general. Factor analysis on the items revealed the three instrumental variables we discussed before: perceived economic and non-economic benefits from loyalty program membership, and perceived non-economic costs: privacy concerns related to loyalty program memberships (Appendix A1). In addition, the survey contains questions about the number of memberships of the four largest gasoline loyalty programs. We use this information to operationalize our fourth instrumental variable "Loyalty program memberships in other industries". The variable definitions are:

$E C B E N_{i}=\quad$ Economic benefits from loyalty program memberships perceived by household $i$

\footnotetext{
${ }^{3}$ From now on we will use "chain" instead of "store" to express that each supermarket chain has several outlets.
} 
$N E C B E N_{i}=\quad$ Non-economic benefits from loyalty program memberships perceived by household $i$;

$P R I V_{i}=\quad$ Privacy concerns w.r.t. loyalty program memberships by household $i$;

$G A Z_{i}=\quad$ Number of loyalty program memberships of gasoline stations held by household $i$, where $i=1, \ldots, I ; I=1909$ (households).

A crucial requirement for the instrumental variables is that they are independent from the attraction to a specific grocery chain. Our four instrumental variables (economic \& noneconomic benefits, privacy concerns, and the number of loyalty program memberships of gasoline stations) are formulated with respect to retailing in general, and therefore not related to any particular grocery chain. By this operationalization, we ensure that we only use exogenous variation in loyalty membership rates, i.e., variation that is not related to store attraction. The exogenous variation allows us to estimate the effect of loyalty programs on behavioral loyalty unbiasedly and consistently (Wooldridge p. 568). The four instruments seem to be strong as well, since their correlations with the loyalty program membership variable $(L P)$ are all significant at the 1-\% level (see Table 3, below the diagonal).

Specifically, the correlation between economic benefits and $L P$ is .20, between non-economic benefits and $L P$ is .08 , between privacy concerns and $L P$ the correlation is -.06 , and between the number of loyalty program memberships of gasoline stations and LP it is .20.

To capture the expected benefits from enrolling in loyalty programs in general, we include economic benefits (ECBEN) in the attraction model. We cannot include a variable such as "expected expenditures in a given chain" as an instrumental variable although it may be a key driver of the program membership decision. The issue is that such a variable is most likely to be very much correlated with the error term in the attraction equation, and therefore it is not a proper instrument. Hence in our model, the non chain-specific variable ECBEN subsumes expected expenditures. 


\section{Household characteristics}

Socio-demographic information is available on household size and net household income of panel members ${ }^{4}$. These socio-demographic variables are included in the model as moderators of the store variables and as main effects in the loyalty program membership equation (see Figure 1). We define the variables as:

$H H S I Z E_{i}=\quad$ Number of persons in household $i$

$H_{H I N C}=\quad$ Monthly net income in 1,000 Euros of household $i$.

\section{Store characteristics}

Some supermarket chains are exclusively located in a limited number of provinces, while others are available nationwide. We obtained the number of outlets of a supermarket chain in each of the twelve provinces of the Netherlands in 2000 from Elsevier Business Information. For each province, the distribution density is measured as the number of outlets of a supermarket chain divided by the number of outlets across all chains. This measure is applied to an individual household, based on its province of residence ${ }^{5}$.

Furthermore, the supermarket chains have been rated on eight dimensions twice per year through well over 8000 exit interviews. We apply the average value of two half-yearly ratings to the yearly period. We conducted a factor analysis extracting two factors. After varimax rotation, the factors can be labeled as: price attractiveness and service level (see Appendix A2). In sum, we introduce the following set of store characteristics:

$D E N S_{i s}=\quad$ Number of outlets of supermarket chain $s$ as a fraction of the total number of supermarket outlets, in the province of residence of household $i$;

\footnotetext{
${ }^{4}$ We also tested the inclusion of additional household characteristics in the model, such as the presence of young children in the household and the educational attainment of the housewife. Because none of the characteristics showed significant effects and theoretical arguments for them were not very strong, we dropped them from the final model.

${ }^{5}$ Since we do not have information about the residence of households at a more detailed level than province, we cannot calculate a more precise proximity measure such as the household's distance to the closest outlet for each supermarket chain.
} 
$P R A T T R_{s}=\quad$ The extent to which supermarket chain $s$ has attractive prices;

$S E R V_{s}=\quad$ The service level of supermarket chain $s$,

where $s=1, \ldots, S ; S=20$ (supermarket chains).

\section{Loyalty program membership and design}

We know the loyalty program memberships of all households in each of the seven loyalty programs for both observation moments (January 1999 and January 2000):

$L P_{i s}=\quad 1$, if household $i$ is member of the loyalty program of supermarket chain $s ; 0$ otherwise.

We also use information on loyalty program design: the saving rate and the discount rate. The saving rate is calculated as the monetary value a consumer saves per euro spent (Liston-Heyes, 2002). We base the saving rate on the monetary value of the gifts and free products participants could save for, which we obtained from web sites and from communication with loyalty program managers. The discount rate is based on Dutch Consumer Reports (2000), which measured the discount rate of the loyalty programs by taking a sample of loyalty program members' receipts and calculating the average discount percentage obtained per loyalty program. In sum, the following loyalty program design variables are used:

$S A V_{s}=\quad$ Saving rate offered by the loyalty program of supermarket chain $s ;$ $D I S C_{s}=\quad$ Discount rate offered by the loyalty program of supermarket chain $s$.

\section{Share-of-Wallet}

We measure purchase behavior as the share-of-wallet in a supermarket chain in a specific year, as defined by the following variable:

$S O W_{i s}=\quad$ Share-of-wallet of household $i$ in chain $s$.

We use one observation moment (one cross-section of 1909 households) for model 
estimation. The share-of-wallet data are taken from one year of purchases symmetrically surrounding January 1999, the month in which the first questionnaire was administered. We aggregate the purchase data over a yearly period since our independent variables (in particular program membership) do not vary at a more frequent rate. We use also one observation moment for model validation (January 2000). In particular, we use the model to predict changes in the share-of-wallet for those households who enter or quit a loyalty program between January 1999 and January 2000. We model share-of-wallet via the attraction of each supermarket chain, as we discuss next.

\section{MODEL}

A model for share-of-wallet yields specific challenges. To be logically consistent, the model must produce estimates between 0 and 1 (range constraint), and the sum of estimates over all stores must equal 1 (sum constraint) (Hanssens, Parsons, \& Schultz 2001, p.121). Attraction models meet these constraints, and have been widely used for modeling market shares (Leeflang, Wittink, Wedel, \& Naert, 2000, p.171). An attraction model can also be applied to household-level shares-of-wallet: the basic idea is that the share-of-wallet of a store depends on its relative attraction to a consumer:

$$
S O W_{i s}=\frac{A_{i s}}{\sum_{s=1}^{S} A_{i s}} .
$$

The attraction of a store $\left(A_{i s}\right)$ is a function of loyalty program membership and store characteristics ${ }^{6}$. We specify the attraction function as a Multi Nominal Logit Model, so that it becomes:

\footnotetext{
${ }^{6}$ Household characteristics show up exactly in the same manner in the nominator and the denominator of the model, and cancel out in the equation for share-of-wallet. Hence in model (2) household characteristics only appear in interaction with store characteristics. We prefer this approach over interactions with store dummies, since it is more parsimonious and the interpretation is more clear. In the equations for store choice and loyalty program membership the household characteristics are included as main effects.
} 


$$
\begin{aligned}
& A_{\text {is }}=\exp \left(\beta_{0}+\beta_{1} L P_{i s}+\beta_{2} L P_{i s} * S A V_{s}+\beta_{3} L P_{i s} * D I S_{s}+\beta_{4} L P_{i s} * H H S I Z E_{i}+\beta_{5} L P_{i s} * H H I N C_{i}\right. \\
& +\beta_{6} \text { DENS }_{\text {is }}+\beta_{7} \text { PRATTR }_{s}+\beta_{8} \text { SERV }_{s}+\beta_{9} \text { DENS }_{\text {is }} * \text { HHSIZE }_{i}+\beta_{10} \text { DENS }_{\text {is }} * \text { HHINC }_{i} \\
& +\beta_{11} \text { PRATTR }_{i s} * \text { HHSIZE }_{i}+\beta_{12} \text { PRATTR }_{i s} * \mathrm{HHINC}_{i}+ \\
& \left.+\beta_{13} \text {SERV }_{\text {is }} * \mathrm{HHZSIZE}_{i}+\beta_{14} \mathrm{SERV}_{\text {is }} * \mathrm{HHINC}_{i}+v_{\text {is }}\right)
\end{aligned}
$$

The correlation table for the variables included in the model can be found in Table 3, above the diagonal; all correlations are .58 or less in absolute value. Each of the interaction variables in equation (2) has been obtained by mean-centering the original variables: $\left(X_{1}-\bar{X}_{1}\right) *\left(X_{2}-\bar{X}_{2}\right)$, where the bar represents the sample mean. While this transformation does not affect the overall multicollinearity in the model, it does allow us to interpret the main effects to hold for an average observation (Gatignon and Vosgerau 2006). The interaction terms that include household size (HHSIZE) and income (HHINC) capture observed household heterogeneity. ${ }^{7}$ They show how a household's deviation from the average size or income influences the value of the store characteristic for evaluating store attraction. For stores that do not have a loyalty program, we exclude the terms with $L P$ from the attraction specification (2).

\section{[Insert Table 3 about here]}

The model accounts for the fact that households differ in the number of stores they visit, because the share-of-wallet of a household is modeled as the attraction of the specific store divided by the sum of the attractions of the stores chosen by this particular household. In this way we also account for competitive loyalty programs, because these enhance the attraction of the competition.

The attraction model is non-linear, and must be transformed to enable estimation of the parameter coefficients. Using the method of log-centering (Nakanishi \& Cooper, 1982), we obtain a log-linear specification from which we can estimate the parameter coefficients:

\footnotetext{
${ }^{7}$ Since we only have one observation per household, we cannot accommodate unobserved heterogeneity.
} 
(3) $\log \frac{S O W_{i s}}{\left(\prod_{s} S O W_{i s}\right)^{1 / S}}=\left(X_{1 i s}-\overline{X_{1 i .}}\right)^{\prime} \beta+\omega_{i s}$,

where $X_{1 i s}$ is the vector with the independent variables from (2), and $\overline{X_{1 i .}}=\frac{1}{S} \sum_{s=1}^{S} X_{1 i s}$.

One issue with (2) is that shares-of-wallet are zero in case a household does not patronize a specific chain during an entire year. An attraction model does not allow for these zeros, because the attraction of a supermarket chain cannot be zero (see equation (2)). Analyzing only those observations with a positive share-of-wallet may lead to biased parameters. That is, share-of-wallet is positive conditional on the store being chosen, and we expect that unobserved factors that influence a household's store choice influence the shareof-wallet of chosen stores as well. Therefore, the error terms of both models are possibly correlated, and we should account for this dependency to obtain unbiased and consistent parameter estimates (Thomas, 2001). Another issue with (2) is the potential endogeneity of loyalty program membership, as discussed before. To solve both issues, we follow the procedure for type-II Tobit models with endogenous variables as recently proposed by Wooldridge (2002, p.567-571).

For model estimation purposes, we introduce a selection variable $C H O I C E_{i s}$, which indicates whether store $s$ is in the choice set of household $i$. We assume that a consumer chooses to visit a supermarket chain $\left(C H O I C E_{i s}=1\right)$ if the underlying utility CHOICE $_{i s}^{*}$ is positive. $C H O I C E_{i s}^{*}$ is linearly dependent on a set of independent variables $X_{2 i s}$. This set consists of the same store and household characteristics as in the attraction function (2). The loyalty program design elements $\left(S A V_{s}\right.$ and $\left.D I S C_{s}\right)$ and instrumental variables are included as well. Store choice is captured by a probit model with pooled coefficients across stores, which allows for the fact that a household may visit multiple stores, i.e., multiple elements of $\left\{C H O I C E_{i 1}, \ldots, C H O I C E_{i S}\right)$ can be equal to one. For each store the probit model yields the 
inverse Mill's ratio, $\lambda_{i s}$, which is calculated as follows:

(4) $\quad \lambda_{\text {is }}=\frac{\varphi\left(X_{2 i s}{ }^{\prime} \eta\right)}{\Phi\left(X_{2 i 1}{ }^{\prime} \eta\right)}$, where $\eta$ is the vector of parameters from the choice model.

This $\lambda_{i s}$ is added, for each chain, as an independent variable to (2) to correct for the interrelation between store choice and share-of-wallet.

The 2SLS procedure requires to predict loyalty program membership by the instrumental variables $\left(E C B E N_{i}, N E C B E N_{i}, P R I V_{i}\right.$, and $\left.G A Z_{i}\right)$ and by all independent variables from the share-of-wallet model (Wooldridge 2002, p. 569). We do exclude the four instruments from the share-of-wallet equation, and thus we meet the identification requirement (Wooldridge, 2002, p. 569). Because the membership decision only takes place in case a loyalty program is available to the consumer, we estimate this equation only for the seven chains with a loyalty program and for those consumers that have chosen the store $\left(C H O I C E_{i s}=1\right)$. The loyalty program membership equation is:

$$
\begin{aligned}
\text { LP }_{i s} & =\alpha_{0}+\alpha_{1} \text { ECBEN }_{i}+\alpha_{2} \text { NECBEN }_{i}+\alpha_{3} \text { PRIV }_{i}+\alpha_{4} \text { GAZ }_{i}+\alpha_{5} \text { SAV }_{s}+\alpha_{6} \text { DIS }_{s}+ \\
& +\alpha_{7} \text { HHSIZE }_{i}+\alpha_{8} \text { HHINC }_{i}+\alpha_{9} \text { DENS }_{i s}+\alpha_{10} \text { PRATTR }_{s}+\alpha_{11} \text { SERV }_{s} \\
& +\alpha_{12} \text { DENS }_{i s} * \text { HHSIZE }_{i}+\alpha_{13} \text { DENS }_{i s} * \text { HHINC }_{i}+ \\
& +\alpha_{14} \text { PRATTR }_{s} * \text { HHSIZE }_{i}+\alpha_{15} \text { PRATTR }_{s} * \text { HHINC }_{i}+ \\
& +\alpha_{16} \text { SERV }_{s} * \text { HHSIZE }_{i}+\alpha_{17} \text { SERV }_{s}^{*} \text { HHSIZE }_{i}+\alpha_{18} \lambda_{i s}+u_{i s}
\end{aligned}
$$

where we again applied mean-centering to compute the interaction terms. The correlation table for the variables included in the model can be found in Table 3, below the diagonal. As we indicated before, the correlations between the instrumental variables and loyalty program membership are all significant at 1-\% level. Furthermore, the instrumental variables are hardly correlated with each other (all correlations below .2 in absolute value), which implies that each of the instruments explains a complementary part of the loyalty program membership decision.

Although loyalty program membership is a binary variable, we use linear regression, since the 2SLS estimation procedure "applies to any kind of endogenous variable, including 
binary and other discrete variables" (Wooldridge, 2002, p.569). ${ }^{8}$ The 2SLS procedure requires us to replace $L P_{\text {is }}$ by the prediction from model (5), $\hat{L} P_{\text {is }}$, in equation (2) for $S O W_{i s}$.

With respect to the moderating effects, Gatignon and Vosgerau (2006) suggest a twostep estimation procedure of models that contain product terms. The first step is to estimate the complete model with all main and moderating effects. In the second step a final model is estimated that leaves out the insignificant moderating effects. We follow this approach for each of the three model components (choice, loyalty program membership, and share-ofwallet).

\section{RESULTS}

As a first step, we estimate the choice model over all observations, and obtain the inverse Mill's ratio $\lambda_{\text {is }}$ needed in the succeeding steps. The complete model reveals that none of the moderating effects between household characteristics and store variables is significant. Therefore we continue with a choice model without these moderators. This model is significant $(p<.01)$ with $L L=-7285.0$ and pseudo- $R^{2}=.248$. Since the store choice equation is merely included to obtain unbiased estimates for the share-of-wallet equation, we will not further discuss it.

\section{[Insert Table 4 about here]}

In the second step, we estimate the model for the loyalty program membership decision (5). Table 4 presents both the complete model (left-hand side), and the final model after deletion of the insignificant moderating effects (right-hand side). Following Gatignon and Vosgerau (2006), we focus on the latter version of the model. The model fit is highly significant $(F(14,1909)=40.97, p<.01)$, and the $R^{2}=.170$. Each of the four instrumental variables is significant and predicts loyalty program membership in the expected way. First,

\footnotetext{
${ }^{8}$ Since a binomial choice model is more common for a binary dependent variable, we also estimated a probit model for $L P_{\text {is }}$. The results are highly similar to those of the regression model.
} 
perceived economic program benefits positively affect loyalty program

membership $\left(\hat{\alpha}_{1}=.075, p<.01\right)$, and the same applies for non-economic benefits

$\left(\hat{\alpha}_{2}=.039, p<.01\right)$. Next, privacy concerns have a negative effect $\left(\hat{\alpha}_{3}=-.018, p<.05\right)$,

implying that privacy concerns indeed withhold customers from participation in loyalty

programs. Finally, the number of gasoline loyalty program memberships hold relates

positively to the membership decision in the supermarket industry $\left(\hat{\alpha}_{4}=.069, p<.01\right)$. We

also find that both higher saving $\left(\hat{\alpha}_{5}=.061, p<.01\right)$ and discount rates $\left(\hat{\alpha}_{6}=.031, p<.01\right)$

stimulate households to enroll. The saving rate effect is significantly larger than the discount rate effect though $\left(\hat{\alpha}_{5}-\hat{\alpha}_{6}=.030 ; t=2.05 ; p<.05\right)$.

In the final step, we include the predicted loyalty program membership from (5) in the attraction model (2), and estimate it conditional on $C H O I C E_{i s}=1$. Again, we first estimate the complete model, and then continue with a model that leaves out the insignificant moderating effects. We base our conclusions on the latter version of the model. The attraction model is overall highly significant $(F(8,5260)=17.49, p<.01)$ with a model fit $R^{2}=.047$. The parameter estimates of the model are reported in Table $5 .^{9}$

[Insert Table 5 about here]

We find that loyalty program membership influences store attraction positively $\left(\hat{\beta}_{1}=.410, p<.01\right)$. The Mills ratio is insignificant, which shows that the error terms of the choice and attraction models are independent. There are no significant moderating effects of saving and discount rates on the impact of loyalty program membership on share-of-wallet. Combined with our findings on the membership decision, we conclude that higher reward rates mainly stimulate customers to participate in the loyalty program, but

\footnotetext{
${ }^{9}$ We note that 2 SLS procedure requires including in the SOW model independent variables that are also used (together with the instruments) to compute the predicted $L P$, which is used in the SOW model as well. We investigated whether this has led to multicollinearity. All VIF-values of the share-of-wallet equation are smaller than 5.4 and the condition index is 12.3 . Since these statistics are well below commonly accepted standards (Hair, Black, Babin, Anderson, \& Tatham, 2006, p. 226-230), we conclude there is no multicollinearity problem.
} 
do not affect the behavioral loyalty of customers once they are enrolled as members. Both socio-demographic variables, household size and income, do not significantly alter the loyalty program effect either.

The store characteristics distribution density and price attractiveness both lead to a higher share-of-wallet. Service level does not have a significant effect. For the sociodemographic moderators, we find that only household size significantly influences the effect of distribution density and price attractiveness on attraction. In particular, household size has a negative moderating impact on distribution density and a positive moderating impact on price attractiveness. The interpretation of these moderating effects can be illustrated as follows (Gatignon and Vosgerau 2006). For a household with an average size (2.55 members, equal to the sample mean) the effect of distribution intensity on attraction is 4.87 and the effect of price attractiveness is .36 (i.e., these are the main effects). For a relatively large household that consists of four members (the sample 75\%-quartile), the effect of distribution intensity is weaker: $3.08\left(=4.87+1.45^{*}-.90\right)$, and the effect of price attractiveness is stronger: $.46(=.36+1.45 * .07)$. These findings are consistent with the prediction that distance matters less for households with larger basket sizes, and that price matters more (Bell \& Lattin, 1998). Conversely, for a relatively small household of two members (the sample $25 \%$-quartile), the effect of distribution intensity is stronger: $4.88\left(=4.87-.55^{*}-.90\right)$, and the effect of price attractiveness is weaker: $.32\left(=.36-.55^{*} .07\right)$. This illustration shows that the coefficients of the store variables distribution density and price attractiveness can only be interpreted as the effect of the store variable at a specific variable of the variable household size (moderator variable).

\section{Effect size and profitability}

The magnitude of the effects is not directly apparent from the parameter estimates, due 
to the non-linear nature of the model. In addition, the coefficients represent the effects of variables on attraction and not on share-of-wallet. To gain better insight into loyalty program effects, we perform effect size calculations, for each supermarket in turn ${ }^{10}$. Table 6 reports the average predicted change in share-of-wallet due to becoming a member of the focal chain's program (keeping everything else constant). Note that we compute the average across all households in the database. Hence the analysis includes customers who are loyalty program members, customers who are member of competing programs, and customers who are not loyalty program members at any chain. Table 6 shows that the loyalty program for all supermarket chains enhances average share-of-wallet across all seven loyalty programs by 4.1 percentage points. There are some differences between loyalty programs, with effect sizes varying between 2.3 and 5.7 percentage points.

[Insert Table 6 about there]

We also calculate whether loyalty programs generate additional customer revenues (Table 6). Additional revenues depend on the loyalty program effect on share-of-wallet, but also on customers' total supermarket expenditures. We calculate the additional revenues from a household due to being a program member as the predicted increase in its share-of-wallet times its total supermarket expenditures. On average, a loyalty program membership yields $€ 240$ additional revenue per customer per year, but again differences exist between supermarket chains (see Table 6). Overall, loyalty programs that are effective in terms of share-of-wallet show large revenue effects as well -- but some deviations exist. In particular, the loyalty program of Albert Heijn generates relatively high additional revenues (€ 328), because the customers of that chain have supermarket expenditures that are higher than average.

\footnotetext{
${ }^{10}$ The procedure described here only provides insight in the effect size and not in the effect of abolishing a loyalty program. Abolishing a loyalty program may lead to strong negative reactions from customers and can trigger competitive reactions as well.
} 
Additional revenues come at a cost: discount and saving rewards. The reward rate is the sum of the discount rate and the saving rate. We calculate the total reward costs as the reward rate times the yearly expenditures per loyalty program member, separately for each chain. ${ }^{11}$ Table 6 provides the average yearly reward costs of the customers per supermarket chain. The net revenue effects, calculated as the difference between the average additional revenues minus the rewarding costs, show results that vary strongly across programs (far right-hand column of Table 6). On average, a loyalty program enhances the net yearly revenues of a customer by $€ 163$, but the effects vary between $€ 91$ and $€ 236$.

\section{[Insert Table 7 about here]}

Loyalty program effectiveness depends on the number of other loyalty programs a customer is enrolled in. To illustrate this, Table 7 shows the effect size calculations by the number of competitive loyalty program memberships. The effect of a loyalty program membership on share-of-wallet is largest for customers who do not hold any competitive memberships (.053). The effect decreases gradually with the number of competitive memberships. For example, for customers with four or more competitive loyalty program memberships the loyalty program effect (.024) is less than half than that for customers without competitive memberships. We elaborate on the implications in the discussion section.

\section{Model validation}

We argue that accounting for endogeneity problems is important in order to obtain an unbiased assessment of loyalty program effectiveness. To explore this, we compare our model with a naïve benchmark model that does not account for endogeneity. This benchmark model uses the observed loyalty program membership variable instead of the predictions from the loyalty program membership model. In the naïve model the loyalty program has a strong

\footnotetext{
${ }^{11}$ This calculation assumes that the actual cost of the reward to the retailer is the same as the value of the reward to the consumer. Since the actual costs (that are unavailable to us) may be lower because retailers pay wholesale prices, net revenue effects may be somewhat understated.
} 
positive influence on attraction $\left(\hat{\beta}_{1}=3.421 ; p<.01\right)$, which is much stronger than the estimate for the model that treats the membership decision as endogenous $\left(\hat{\beta}_{1}=.410\right)$.

[Insert Figure 2 about here]

We used the estimates of the naïve model to compute the effect of membership on share-of-wallet. The naïve model predicts that a member has a share-of-wallet that is on average 29.8 percentage points higher than a non-member, which corresponds very closely to the average member- versus non-member difference in share-of-wallet based on the raw data (last column of Table 1). The effect size estimate from the naïve model that ignores endogeneity (29.8 percentage points) is on average more than seven times higher than the average estimate for the model that accounts for endogeneity (4.1 percentage point).

To validate both models we assess to what extent both models can predict changes in shares-of-wallet for households that (dis)adopt a loyalty program membership. Since we estimate both models on cross-sectional variation only (remember that the estimation sample is a cross-section), predicting longitudinal within-household effects of changing loyalty membership represents a strong test of the validity of the estimates (Van Dijk, Van Heerde, Leeflang, and Wittink (2004) use the same approach).

We select those household-store combinations that changed loyalty program memberships in the validation sample (January 2000) relative to the estimation sample (January 1999). To avoid truncation problems, we limit ourselves to those cases in which the household has been customer of the specific chain in both years $\left(C H O I C E_{i s}=1\right.$ for $\left.t=1,2\right)$. We have 263 household-store combinations in which the household adopted a new loyalty program, and 140 combinations in which the household disadopted a loyalty program. For these 403 cases we predict the change in share-of-wallet between the estimation and validation sample moments. We compare the actual change with the predicted change in share-of-wallet according from models with and without endogeneity correction by computing 
the MSE (mean squared error) and MAPE (mean absolute percentage error) (Leeflang et al., 2000, p.506). The model with endogeneity correction has an MSE $=.014$ and $\mathrm{MAPE}=35.9 \%$, whereas the benchmark model achieves MSE $=.254$ and MAPE $=513.3 \%$. Overall, we find that the model with endogeneity correction predicts the changes in share-of-wallet due to membership changes considerably better than the naïve benchmark model that does not accommodate endogeneity.

\section{DISCUSSION}

We studied the effects of seven loyalty programs on share-of-wallet using market-wide panel data on supermarket purchases. Our study is the first to account for the endogenous nature of loyalty program membership by specifying a model for the loyalty program decision and using instrumental variables such as the attitude towards loyalty programs in general. We find a significant positive yet small effect (4.1 percentage points) of loyalty program membership on share-of-wallet. This effect is seven times smaller than is suggested by a naïve model (29.8 percentage points), which ignores endogeneity. We show that the predictive validity of the proposed model is much better than for the naïve model. In terms of profitability, we find that each program is able to generate more additional revenues than additional costs in terms of saving and discount rewards.

\section{Managerial implications}

The results of this study could help managers to improve their decisions concerning loyalty programs. A company (re)considering the use of such a program should realize that loyalty programs are generally effective in enhancing share-of-wallet, but that the effects are easily overstated. A company that runs a loyalty program should therefore closely monitor its effectiveness. Our results show that this is not trivial. Loyalty programs aim to enhance purchase behavior, but the company's best customers are the most likely to subscribe as 
members. This leads to endogeneity problems, which invalidate a simple comparison of purchase behavior of loyalty program members versus non-members (as in Table 1). Valid assessments can be obtained through a model that accounts for the fact that the membership decision is endogenous.

Loyalty program members and non-members are substantially different in purchase behavior (Van Heerde \& Bijmolt, 2005). However, the bad news for loyalty program managers is that our results suggest that self-selection is the primary driver of share-of-wallet differences between loyalty program members and non-members. We find that the effect of membership on share-of-wallet is seven times larger for a model without than a model with endogeneity. Put differently, $86 \%$ of the effect of being a member on share-of-wallet vanishes if we account for the endogenous nature of the membership decision. Self-selecting members are already loyal to the store, and enrolling in the loyalty program allows them to reap saving and discount rewards without becoming more loyal. The good news is that the remaining $14 \%$ of the effect is due to exogenously driven variation in loyalty program membership, i.e., due to factors that are unrelated to store loyalty. Our message is that if a manager succeeds in creating loyalty program membership based on these "exogenous factors", the loyalty program can increase shares-of-wallet significantly. We elaborate on this now.

A first suggestion to create "exogenous" loyalty program membership is to pay careful attention to loyalty program design, because it has a significant impact on the likelihood of signing up for the program. This implies that it is useful to clearly communicate the financial benefits to non-members, which are either delayed or direct rewards. Delayed rewards are rear-loaded incentives and they are compatible with the main purpose of loyalty programs to increase long-term loyalty and retention (Taylor \& Neslin, 2005), whereas direct rewards (single-shot price discounts) are front-loaded incentives that seem incompatible with longterm program goals (see also Zhang et al., 2000). When focusing on the trade-off between 
direct and delayed rewards, managers are advised to reward customers predominantly via delayed rewards, such as a saving feature, since the impact on the enrollment decision is stronger than for direct discounts. This finding suggests that consumers act irrationally, because (ceteris paribus) direct discounts do not create switching costs whereas delayed rewards do. The finding that consumers overvalue the benefits of saving is consistent with lab results (Hsee et al., 2003; Van Osselaer et al., 2003).

Offering higher saving (and discount) rates costs money though. Our analyses show that the program that generates the highest net revenues per customer is Albert Heijn. Its saving rate $(1 \%)$ and discount rates $(4 \%)$ are quite close to the average across programs. This chain appears to find the right balance between offering rewards that entice consumers to enroll, but that do not cost too much. A chain that does not find the right balance is Jan Linders. It offers the lowest saving reward rate and the highest discount rate across all programs, which is just the opposite from what leads to high participation rates according to our model (Table 2). Moreover, this loyalty program incurs so many reward costs that net revenues are barely positive (Table 6).

To increase participation rates it is also important to consider the profile of consumers that are likely to sign up for a loyalty program. Our results suggest that a key characteristic is a positive attitude towards loyalty programs in general. We find that there are two components of this attitude: perceived economic and non-economic benefits (Table 4). Obviously, managers may enhance the perceived economic benefits by communicating the attractive discounts and saving rewards that participation brings. Alternatively, they may stress the benefits that a consumer foregoes by shopping at a retailer that does not offer a loyalty program, since this is the variable that also loads highly on the factor economic benefits (Table A.1). To enhance the perceived non-economic benefits, managers may stress the joy and connectedness that the program brings, which could even be more important than 
low prices (Table A.1). Furthermore, managers could search for original, entertaining and joyful "soft benefits" that are cost efficient but enhance the non-economic benefits customers derive from the program.

A factor that inhibits loyalty program participation are privacy concerns (Table 4). Current privacy legislation protects customer privacy to a great extent, and some of their fears might be irrational. In order to reduce customers' privacy fears, a retail company should invest in proper communication to customers about privacy protection guarantees and the constraints on data usage, and of course, act accordingly (Phelps et al., 2000).

Interestingly, we find that once a consumer has decided to enroll in a particular program, the effect of membership on share-of-wallet is independent of the saving rate and discount rate. A possible explanation is that once a consumer participates in a particular program, s/he becomes more loyal to that chain (significant main effect of $L P$ on attraction), and therefore differences in reward rates across programs are less salient and actionable. Moreover, we also find that household size does not significantly moderate the loyalty program effect. This implies that once a household has enrolled, larger households do not increase their share more than smaller households. However, since total grocery expenditures are higher for larger households, absolute increases in expenditures due to loyalty program membership are higher than for smaller households. The same applies for richer versus poorer households.

The effect of a loyalty program decreases with the number of competitive loyalty program memberships. Retailers should therefore focus on attracting customers with a low number of program memberships. A design that rewards loyalty progressively (i.e., reward tiers such as silver and golden members) may withhold customers of holding many loyalty program memberships. 


\section{Limitations and further research}

We undertook a market-wide study of all loyalty programs in the Dutch supermarket industry and found overall positive effects of programs on share-of-wallet. Given that the relationship proneness and product category involvement of consumers is low in this industry, we could expect these effects to be even larger in other industries, such as clothing retailing (De Wulf et al., 2001). Furthermore, in the empirical application several competitors use loyalty programs, and households hold several loyalty program members simultaneously. As a consequence, an individual retailer derives only limited competitive advantage from the loyalty program. Consumers can optimize their loyalty program benefits by 'cherry-picking' among the several loyalty programs. The qualitative results of our study may not generalize to situations in which only one retailer has a loyalty program. The empirical findings of Drèze and Hoch (1998) suggest that the effectiveness of a loyalty program is stronger under these circumstances.

Further, the loyalty program designs studied in this paper offer linear reward structures, do not distinguish between customer tiers (e.g., silver, gold and diamond members), and charge no membership fees. In that sense the relatively low effects on loyalty that we find provide perhaps a lower bound of the effect a loyalty program may generate. Companies could potentially gain from differentiating their loyalty programs from other programs. One particularly interesting direction of further empirical investigation is whether it is beneficial to the firm to offer convex saving point schedules (Nunes \& Drèze 2006), i.e., rewards that increase with the number of points saved in the (recent) past. Another option is a multi-tier program where every tier brings additional benefits. Such programs are often seen in frequent flyer programs (Von Wangenheim \& Bayón, 2006), but are less common in retailing (Nunes \& Drèze 2006). Related to this is the issue of membership fees. Where membership fees may withhold some customers from participation, it may select the more 
profitable customers and be more effective in enhancing members' loyalty (Dick and Lord 1998). Managers could use field experiments in test markets to measure customer reactions to such refinements (see Drèze \& Hoch (1998) for an interesting example).

Further, share-of-wallet is a behavioral loyalty measure, and the development of attitudinal loyalty is also relevant (Yi \& Jeon, 2003). Behavioral loyalty not supported by attitudinal loyalty is spurious (Dick \& Basu, 1994), in the sense that it can easily be attacked by competitors. More research is needed on the extent to which attitudinal versus behavioral loyalty is enhanced by loyalty programs. Also of interest is the question to what extent the various drivers (economic, psychological, and social) play a mediating role in forming behavioral loyalty. In particular, it would be interesting to study the proposed dimensions of belonging, identification or reciprocity (as suggested by Bhattacharya \& Sen, 2003). A fruitful extension to current research on these issues would be an examination of how customers deal with multiple memberships. How do positive attitudes towards a company develop if several companies provide loyalty benefits at the same time? More research is required as well on the effects of social benefits (e.g. special shopping nights or newsletters for members) on affective commitment and behavioral loyalty (Bolton, Lemon, \& Verhoef, 2004).

Our model, as any model, is incomplete. One limitation is that our model for loyalty program membership does not capture the entire variance to join the loyalty program. However, we note that the 2SLS estimator is consistent even when we do not have perfect fit in the membership equation (Wooldridge, 2002, p. 568). The intuition behind this is that the endogenous part of the variation in membership is explained by the independent variables that are also used to explain share-of-wallet. The exogenous part is explained by the four instrumental variables, which are all significant. By using predicted program membership ("LP-hat") in the share-of-wallet model together with the independent variables, the parameter estimate for "LP-hat" is based on its exogenous variation only. 
Our reduced-form 2SLS approach is not the only approach to measure the effectiveness of loyalty programs while accounting for endogeneity. Other useful approaches include switching regression models (Taylor \& Neslin, 2005) and structural models that capture the optimizing behavior of consumers (Lewis, 2004; Erdem \& Keane, 1996; Gönül \& Srinivasan, 1996). Alternatively, we could use time series analysis in case a loyalty program is introduced within the observation period (which is not the case for our data). Customers could be tracked over time to check whether their behavioral loyalty increases due to the newly introduced program (Drèze \& Hoch, 1998). Another approach is to find comparable units to filter out a common unobservable (Chamberlain \& Griliches, 1975). One could match member customers with non-member customers based on e.g., demographics, and attribute differences in purchase behavior to the loyalty program.

Since we use an attraction model for share-of-wallet, we account for the structural interdependence of the share-of-wallets of a household between different stores. However, one model limitation is that we do not allow for between-store error correlations within the various model components (loyalty program membership, chain choice, and share-of-wallet). This choice may affect the asymptotic efficiency of our estimates. However, we decided to treat the errors between stores as independent, because this allows us to use the univariate Tobit-II model with endogenous regressors proposed by Wooldridge (2002, p. 568), separately for each store. The consistency of the 2SLS estimator has been demonstrated for this model (Wooldridge 2002, p. 568). Unfortunately, the literature does not provide us yet with a multivariate Tobit-II model with endogenous regressors. Wooldridge (2002, p. 570) argues that maximum likelihood estimation for such a model is very complex and less robust than his 2SLS procedure. Since our key objective is to correct for endogeneity, we opt for a well-documented and consistent 2SLS approach for a univariate Tobit II model.

We focus on share-of-wallet as our dependent variable, but loyalty programs might 
also affect total category expenditures. In fact, Kopalle and Neslin (2003) find that the elasticity of category demand can be one of the drivers of loyalty program success. This topic is definitely worth further empirical study. We believe that the issue of category elasticity is especially relevant for shopping goods (such as apparel), and less relevant for grocery products that are the topic of this study.

Another limitation of our study is that we were not able to incorporate all costs related to the loyalty program. We studied the profitability of loyalty programs by measuring the effects on purchase behavior versus the rewarding costs. However, a loyalty program also incorporates maintenance costs, such as operation of data warehouses, administration of rewards, logistics of rewards availability in the stores, etc. We had no access to estimates of such costs, which might diminish the profitability of the loyalty programs even further. On the other hand, we assumed that all saving points were redeemed, which is usually not the case (Drèze \& Hoch, 1998). Overall, our benefit-cost comparison reveals to what extent additional revenues compensate the maximal additional rewards given to the customer.

Some additional benefits may be derived from the loyalty program as well. Our study focused on loyalty programs as a means of improving loyal behavior, but did not consider that a company might be motivated to introduce a loyalty program in order to obtain purchase data (Day, 2000; Leenheer \& Bijmolt, 2003; Mauri, 2003). A loyalty program provides the company with full information of customers' purchase behavior, and could be enriched with socio-demographics and causal information such as price promotions. Rossi, McCulloch, and Allenby (1996) show the value of using this information for target marketing to certain customer groups. Such a strategy of direct marketing fulfills customer needs more specifically, so that marketing budgets are spent more efficiently.

Overall, our research shows that loyalty programs have significant positive yet small effects on share of wallet. The effects are strongly overestimated, however, if the endogenous 
nature of the membership decision is ignored. We hope that this paper sheds new light on the question whether loyalty programs are really effective, and that it will stimulate additional research on this intriguing issue. 


\section{FIGURE 1}

Instrumental variables

- Perceived benefits and costs of loyalty programs in general

- LP memberships in other industries

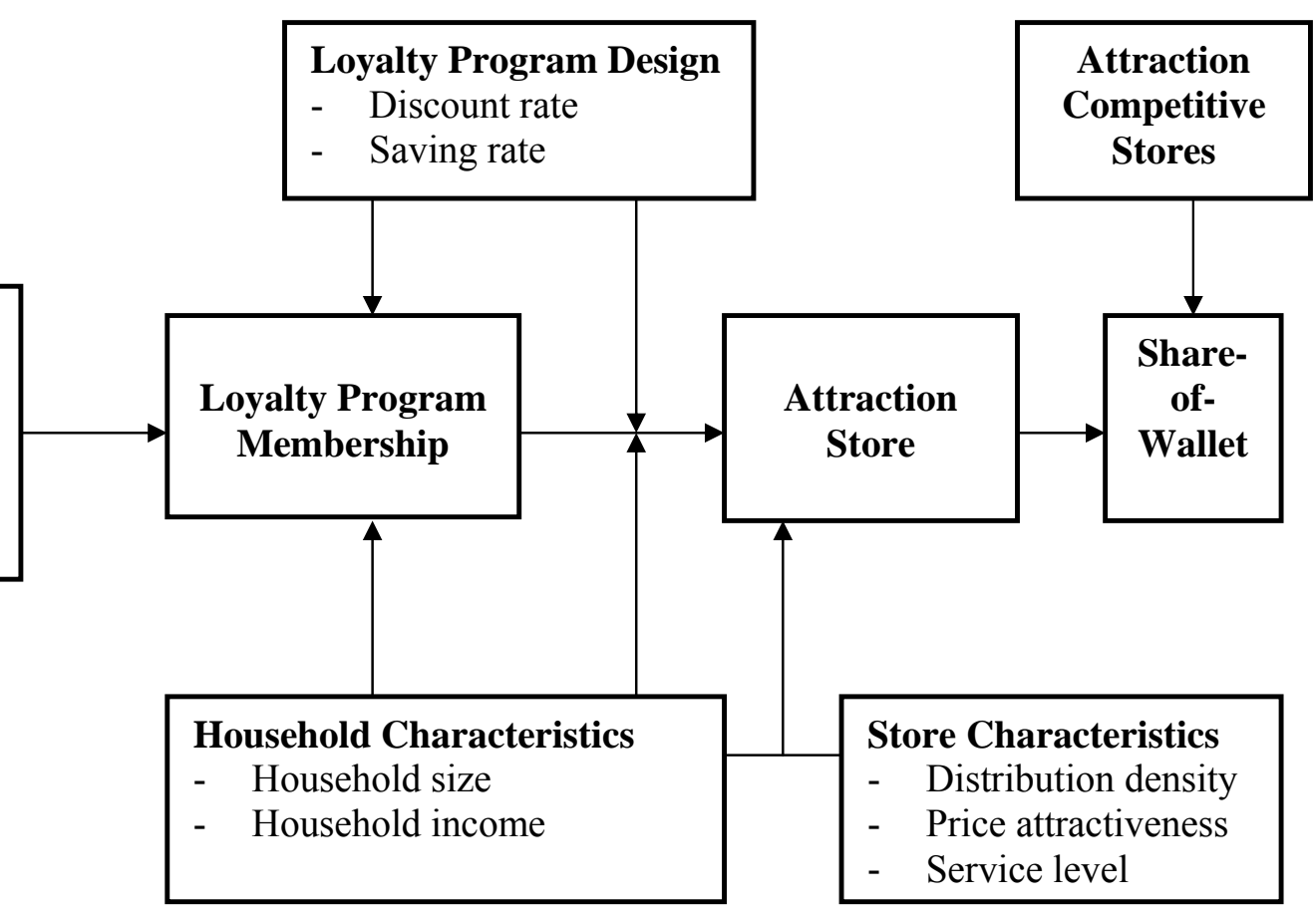


FIGURE 2

Changes in Share-of-Wallet Due to Loyalty Program Membership

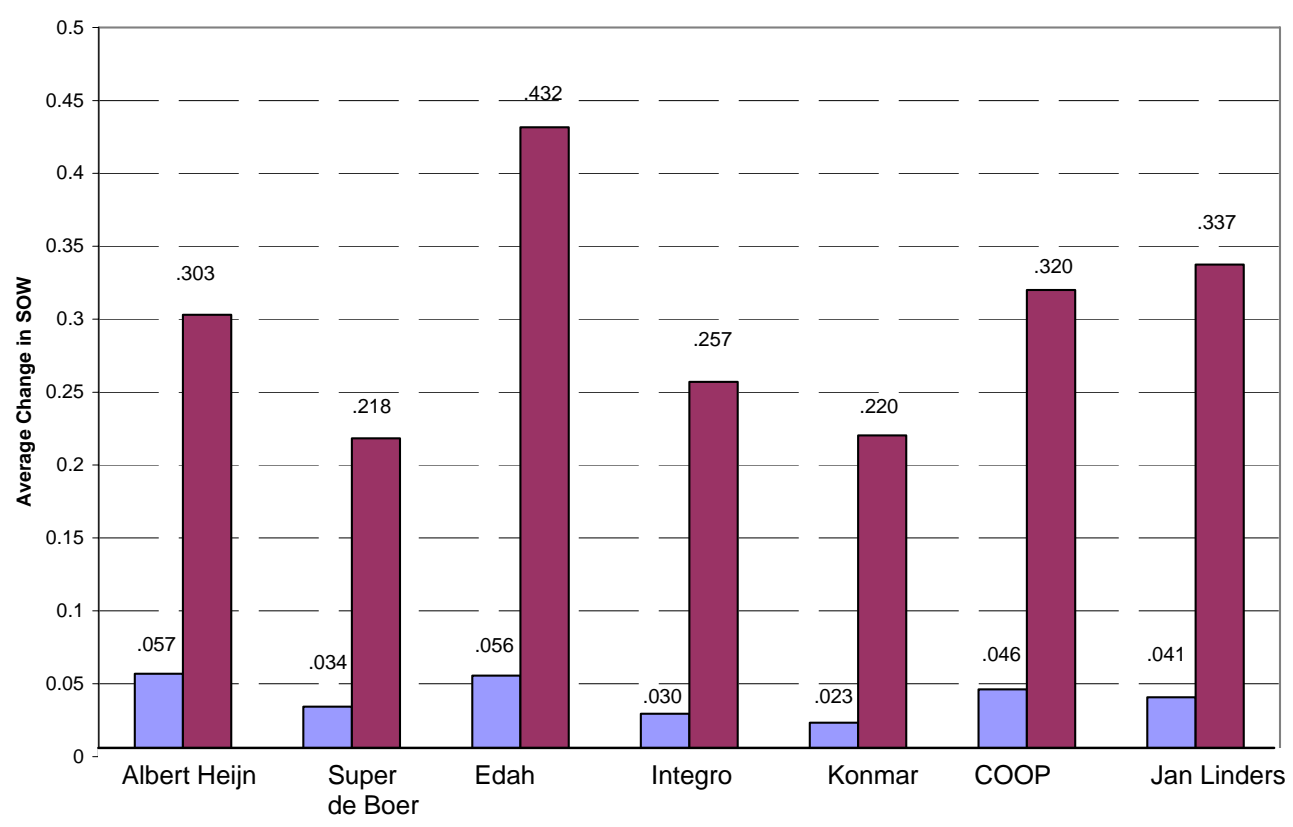

$\square$ Accounting for endogeneity; Average effect size: .041

$\square$ Not accounting for endogeneity; Average effect size: .298 
TABLE 1

Information on Supermarket Chains with a Loyalty Program (LP)

\begin{tabular}{|c|c|c|c|c|c|c|c|c|c|}
\hline & $\begin{array}{r}\text { LP Saving } \\
\text { Rate (SAV) }\end{array}$ & $\begin{array}{r}\text { LP Discount Rate } \\
\text { (DISC) }\end{array}$ & $\begin{array}{r}\text { Market } \\
\text { Share } \\
\%\end{array}$ & $\begin{array}{r}\text { Market Share } \\
\text { Rank }\end{array}$ & $\begin{array}{l}\text { \# Chains } \\
\text { Visited by } \\
\text { Customers }\end{array}$ & $\begin{array}{r}\text { \% Loyalty } \\
\text { Program Members }\end{array}$ & $\begin{array}{r}\text { SOW } \\
\text { LP } \\
\text { members }\end{array}$ & $\begin{array}{r}\text { SOW } \\
\text { Non-LP } \\
\text { members }\end{array}$ & $\begin{array}{l}\text { Difference SOW } \\
\text { LP/Non-LP members }\end{array}$ \\
\hline Albert Heijn & $1.0 \%$ & $4 \%$ & $24 \%$ & 1 & 4.56 & $82 \%$ & .37 & .13 & .24 \\
\hline Super de Boer & $.5 \%$ & $0 \%$ & $9 \%$ & 3 & 5.04 & $59 \%$ & .32 & .11 & .21 \\
\hline Edah & $2.0 \%$ & $5 \%$ & $8 \%$ & 4 & 5.07 & $75 \%$ & .30 & .02 & .28 \\
\hline Integro & $.6 \%$ & $2 \%$ & $7 \%$ & 6 & 5.18 & $49 \%$ & .44 & .07 & .37 \\
\hline Jan Linders & $.5 \%$ & $9 \%$ & $1 \%$ & 18 & 5.08 & $63 \%$ & .37 & .09 & .28 \\
\hline Average & $1.3 \%$ & $4 \%$ & & & 5.06 & $64 \%$ & .36 & .07 & .29 \\
\hline
\end{tabular}


TABLE 2

Data Sources

\begin{tabular}{ll}
\hline Source & Obtained data \\
\hline GfK Panel Services 1998-2000 & $\begin{array}{l}\text { Purchase behavior of Dutch households in } \\
\text { supermarkets, loyalty program memberships, } \\
\text { perceived economic and non-economic } \\
\text { benefits of loyalty programs, privacy } \\
\text { concerns, and socio-demographics of the } \\
\text { households }\end{array}$ \\
Dutch Consumer Reports 2000 & $\begin{array}{l}\text { Discount rate of Dutch supermarket loyalty } \\
\text { programs }\end{array}$ \\
GfK Christmas/Summer report & $\begin{array}{l}\text { Scores on store characteristics for twenty } \\
\text { largest Dutch supermarket chains. }\end{array}$ \\
Elsevier Business Information 2000 & Outlet locations of Dutch supermarket chains \\
\hline
\end{tabular}



TABLE 3

Correlations for all observations (above diagonal) and for chains with loyalty programs only (below diagonal). ${ }^{\text {a }}$

\begin{tabular}{|c|c|c|c|c|c|c|c|c|c|c|c|c|c|c|}
\hline & & SOW & $\mathrm{LP}^{\mathrm{b}}$ & $\mathrm{SAV}^{\mathrm{c}}$ & DISC $^{c}$ & DENS & PRATT & SERV & HHSIZE & HHINC & ECBEN & NECBEN & PRIV & GAZ \\
\hline Share-of-Wallet & SOW & 1 & $.35 * *$ & & & $.19^{* *}$ & $-.09 * *$ & $.12 * *$ & -.01 & -.01 & $-.05 * *$ & $.04 *$ & -.01 & $-.07 * *$ \\
\hline LP membership & $\mathrm{LP}^{\mathrm{b}}$ & $.58 * *$ & 1 & & & $.39 * *$ & $-.56^{* *}$ & $.38^{*}$ & $.03 *$ & $.04^{* *}$ & $.08^{* *}$ & $.15^{* *}$ & -.02 & $.11^{* *}$ \\
\hline Saving rate $\%$ & $\mathrm{SAV}^{\mathrm{c}}$ & -.01 & $.19^{* *}$ & 1 & & & & & & & & & & \\
\hline Discount rate $\%$ & DISC $^{\mathrm{c}}$ & .03 & $.10 * *$ & $.49 * *$ & 1 & & & & & & & & & \\
\hline Distribution Density & DENS & $.16^{* *}$ & $.23 * *$ & $-.08 * *$ & -.01 & 1 & $-.58 * *$ & $.25 * *$ & .00 & .01 & -.01 & .03 & -.01 & .01 \\
\hline Price attractiveness & PRATTR & $-.10 * *$ & $-.22 * *$ & $.42 * *$ & $.39 * *$ & $-.72 * *$ & 1 & $-.40 * *$ & .01 & $-.03 *$ & $-.03 *$ & $-.03 *$ & .00 & -.03 \\
\hline Service level & SERV & $.08 * *$ & .03 & $-.59 * *$ & $.04^{*}$ & $.27 * *$ & $-.41 * *$ & 1 & -.01 & $.03 *$ & $.03 *$ & .02 & -.00 & -.01 \\
\hline Household size & HHSIZE & -.01 & .02 & $.05^{*}$ & .01 & -.02 & .03 & $-.06 * *$ & 1 & .02 & .02 & -.01 & $-.07 * *$ & $.15 * *$ \\
\hline Household income & HHINC & .02 & .03 & .01 & .00 & .02 & -.02 & .03 & .03 & 1 & $.07 * *$ & $-.07 * *$ & $-.06^{* *}$ & $.14^{* *}$ \\
\hline Economic benefits & ECBEN & $.08 * *$ & $.20 * *$ & .02 & $.07 * *$ & -.03 & $.05 * *$ & .03 & .02 & $.07 * *$ & 1 & .00 & -.02 & $.19^{* *}$ \\
\hline Non-economic benefits & NECBEN & $.15^{* *}$ & $.08^{* *}$ & $.04 *$ & .01 & -.03 & .02 & -.03 & -.02 & $-.08 * *$ & -.03 & 1 & $-.06^{* *}$ & $.05^{* *}$ \\
\hline Privacy concerns & PRIV & -.03 & $-.06 * *$ & .01 & .02 & -.01 & .01 & .01 & $-.06 * *$ & $-.07 * *$ & -.04 & $-.06 * *$ & 1 & $-.11 * *$ \\
\hline \# LPs gasoline sector & GAZ & -.03 & $.20 * *$ & $-.05 * *$ & $-.07 * *$ & -.01 & -.04 & -.02 & $.14^{* *}$ & $.13^{* *}$ & $.18^{* *}$ & .03 & $-.12 * *$ & 1 \\
\hline
\end{tabular}

** Significant at .01 level; * Significant at .05 level

${ }^{a}$ The above-diagonal correlations are relevant for the SOW and Choice models, whereas the below-diagonal correlations are relevant for the LP model.

b Since the variable LP is binary, the numbers in this column/row refer to Spearman's rho.

${ }^{c}$ Since the saving (SAV) and discount rate (DISC) are only measured conditional on the chain having a loyalty program, the correlations for these variables can be reported for these chains only (therefore, only correlations for these variables are presented in the area below the diagonal). 
TABLE 4

Results of the Loyalty Program Membership Model

\begin{tabular}{|c|c|c|c|c|c|}
\hline \multirow{2}{*}{ Independent Variable } & & \multicolumn{2}{|c|}{$\begin{array}{l}\text { Initial model: } \\
\text { all moderators } \\
\end{array}$} & \multicolumn{2}{|c|}{$\begin{array}{l}\text { Final model: } \\
\text { only significant moderators }\end{array}$} \\
\hline & & $\begin{array}{c}\text { Parameter } \\
\text { Estimate }\end{array}$ & $t$-Value & $\begin{array}{c}\text { Parameter } \\
\text { Estimate }\end{array}$ & $t$-Value \\
\hline Constant & $\alpha_{0}$ & .835 & $4.88^{* * *}$ & .896 & $5.32 * * *$ \\
\hline Economic benefits (ECBEN) & $\alpha_{1}$ & .076 & $8.91 * * *$ & .075 & $8.81^{* * *}$ \\
\hline Non-economic benefits (NECBEN) & $\alpha_{2}$ & .038 & $4.67^{* * *}$ & .039 & $4.75^{* * *}$ \\
\hline Privacy concerns (PRIV) & $\alpha_{3}$ & -.017 & $-2.65 * *$ & -.018 & $-2.12 * *$ \\
\hline \# LPs gasoline sector (GAZ) & $\alpha_{4}$ & .070 & $7.18^{* * *}$ & .069 & $7.07^{* * *}$ \\
\hline Saving rate \% (SAV) & $\alpha_{5}$ & .062 & $3.12 * * *$ & .061 & $3.07 * * *$ \\
\hline Discount rate \% (DISC) & $\alpha_{6}$ & .031 & $5.24 * * *$ & .031 & $5.25 * * *$ \\
\hline Household size (HHSIZE) & $\alpha_{7}$ & .002 & .18 & .002 & .34 \\
\hline Household income (HHINC) & $\alpha_{8}$ & -.040 & $-2.96^{* * *}$ & -.027 & $-2.81 * * *$ \\
\hline Distribution density (DENS) & $\alpha_{9}$ & -.003 & -.54 & -.005 & -.89 \\
\hline Price attractiveness (PRATTR) & $\alpha_{10}$ & -.061 & $-2.65 * * *$ & -.057 & $-2.49 * * *$ \\
\hline Service level (SERV) & $\alpha_{11}$ & -.023 & -.59 & -.017 & -.44 \\
\hline DENS*HHSIZE & $\alpha_{12}$ & .079 & .84 & & \\
\hline DENS*HHINC & $\alpha_{13}$ & .006 & .05 & & \\
\hline PRATTR* HHSIZE & $\alpha_{14}$ & .007 & .70 & & \\
\hline PRATTR*HHINC & $\alpha_{15}$ & -.016 & -1.36 & & \\
\hline SERV*HHSIZE & $\alpha_{16}$ & -.009 & -.67 & & \\
\hline SERV*HHINC & $\alpha_{17}$ & .032 & $1.98^{* *}$ & .044 & $2.12 * * *$ \\
\hline \multirow[t]{2}{*}{ Mills ratio $(\lambda)$} & $\alpha_{18}$ & -.185 & $-2.00 * *$ & -.218 & $-2.40^{* *}$ \\
\hline & $R^{2}$ & .171 & & .170 & \\
\hline
\end{tabular}


TABLE 5

Results of the Attraction model for Share-of-Wallet

\begin{tabular}{|c|c|c|c|c|c|}
\hline \multirow{3}{*}{ Independent Variable: } & & \multicolumn{2}{|c|}{$\begin{array}{l}\text { Initial model: } \\
\text { all moderators }\end{array}$} & \multicolumn{2}{|c|}{$\begin{array}{c}\text { Final model: } \\
\text { only significant moderators }\end{array}$} \\
\hline & & Parameter & $t$-Value & Parameter & $t$-Value \\
\hline & & Estimate & & Estimate & \\
\hline Constant & $\beta_{0}$ & .049 & .45 & .056 & .52 \\
\hline LP & $\beta_{1}$ & .431 & $3.81^{* * *}$ & .410 & $3.69^{* * *}$ \\
\hline $\mathrm{LP} * \mathrm{SAV}$ & $\beta_{2}$ & .014 & .40 & & \\
\hline LP*DISC & $\beta_{3}$ & -.030 & -.30 & & \\
\hline LP*HHSIZE & $\beta_{4}$ & -.000 & -.17 & & \\
\hline LP*HHINC & $\beta_{5}$ & -.023 & -.96 & & \\
\hline Distribution Density (DENS) & $\beta_{6}$ & 4.857 & $5.52 * * *$ & 4.867 & $5.63^{* * *}$ \\
\hline Price Attractiveness (PRATTR) & $\beta_{7}$ & .414 & $8.54^{* * *}$ & .364 & $8.26^{* * *}$ \\
\hline Service Level (SERV) & $\beta_{8}$ & -.035 & -1.12 & -.019 & -.63 \\
\hline DENS*HHSIZE & $\beta_{9}$ & -.869 & $-2.74 * * *$ & -.899 & $-2.93 * * *$ \\
\hline DENS*HHINC & $\beta_{10}$ & .157 & .40 & & \\
\hline PRATTR * HHSIZE & $\beta_{11}$ & .072 & $2.58^{* *}$ & .071 & $2.98^{* * *}$ \\
\hline PRATTR *HHINC & $\beta_{12}$ & -.046 & -1.25 & & \\
\hline SERV*HHSIZE & $\beta_{13}$ & -.003 & -.17 & & \\
\hline SERV*HHINC & $\beta_{14}$ & -.157 & -.96 & & \\
\hline Mills ratio $(\lambda)$ & & -.049 & -.47 & -.047 & -.53 \\
\hline$R^{2}$ & & .048 & & .047 & \\
\hline
\end{tabular}


TABLE 6

Changes in Per-Customer Share-of-Wallet and (Net) Revenues Due to Program Membership

\begin{tabular}{|c|c|c|c|c|c|}
\hline $\begin{array}{l}\text { Supermarket } \\
\text { Chain }\end{array}$ & $\Delta \mathrm{SOW}^{*}$ & $\Delta$ Revenues $^{* *}$ & $\Delta$ Costs $^{* *}$ & & $\Delta$ Net Revenues ${ }^{* *}$ \\
\hline Albert Heijn & .057 & $€ \quad 328.72$ & $€ \quad 92.37$ & $€$ & 236.35 \\
\hline Super de Boer & .034 & 196.35 & $€ \quad 6.06$ & $€$ & 190.29 \\
\hline Edah & .056 & 311.72 & 88.34 & $€$ & 223.38 \\
\hline Integro & .030 & 181.02 & $€ \quad 38.01$ & $€$ & 143.01 \\
\hline Konmar & .023 & 151.38 & 60.53 & $€$ & 90.85 \\
\hline $\mathrm{COOP}$ & .041 & 249.36 & 105.90 & $€$ & 143.46 \\
\hline Jan Linders & .046 & $€ \quad 259.46$ & $€ \quad 147.16$ & $€$ & 112.30 \\
\hline Average & .041 & 239.72 & $€ \quad 76.91$ & $€$ & 162.81 \\
\hline
\end{tabular}

Average predicted change in share-of-wallet due to becoming a member of the focal chain's program (keeping everything else constant)

${ }^{* *}$ Average predicted change in Euros per year 
TABLE 7

Changes in Per-Customer Share-of-Wallet Due to Program Membership: The Influence of Competitive Loyalty Program Memberships

\begin{tabular}{cc}
\hline $\begin{array}{c}\text { Number of competitive } \\
\text { LP-memberships }\end{array}$ & $\Delta$ SOW $^{*}$ \\
\hline 0 & .053 \\
1 & .048 \\
2 & .039 \\
3 & .033 \\
4 or more & .024
\end{tabular}

* Average predicted change in share-of-wallet due to becoming a member of the focal chain's program (keeping everything else constant). 
APPENDIX

TABLE A.1

Attitudes towards Loyalty Programs by Panel Households

\begin{tabular}{|c|c|c|c|c|c|}
\hline & \multirow[t]{2}{*}{ Mean } & \multirow[t]{2}{*}{ S.d. } & \multicolumn{3}{|c|}{ Rotated Factor Loadings (Varimax) } \\
\hline & & & $\begin{array}{r}\text { Non- } \\
\text { economic } \\
\text { Benefits } \\
(N E C B E N) \\
\end{array}$ & $\begin{array}{r}\text { Economic } \\
\text { Benefits } \\
(E C B E N)\end{array}$ & $\begin{array}{r}\text { Non- } \\
\text { economic } \\
\text { Costs } \\
(P R I V) \\
\end{array}$ \\
\hline I feel stronger connected to a retailer of which I hold a loyalty card. & 2.59 & .991 & .848 & .230 & -.144 \\
\hline Having a loyalty card makes me feel like a regular customer. & 2.79 & .964 & .790 & .306 & -.089 \\
\hline I prefer loyalty programs over lower prices. & 2.42 & .907 & .784 & .175 & .051 \\
\hline I enjoy participation in loyalty or saving programs. & 3.06 & 1.055 & .649 & .403 & -.262 \\
\hline If a retailer does not have a loyalty program, I miss important benefits. & 3.13 & 1.064 & .134 & .886 & .006 \\
\hline Loyalty and saving programs offer attractive benefits. & 3.40 & .912 & .369 & .769 & -.119 \\
\hline I am paying more attention on special offers because of the loyalty card. & 3.06 & 1.153 & .451 & .635 & -.039 \\
\hline The registration systems of loyalty programs infringe on my privacy. & 2.91 & .960 & -.101 & -.048 & .978 \\
\hline
\end{tabular}

* All items are measured on a 5-point scale (1=totally disagree, $5=$ totally agree).

TABLE A.2

Factor Analysis on the Ratings of Supermarket Chains on Store Dimensions

\begin{tabular}{lcccc}
\hline & Mean & S.d. & \multicolumn{2}{c}{ Rotated Factor Loadings (Varimax) } \\
\cline { 3 - 4 } & & & $\begin{array}{c}\text { Service Level } \\
\text { (SERV) }\end{array}$ & $\begin{array}{c}\text { Price Attractiveness } \\
(P R A T T R)\end{array}$ \\
\hline Tidiness & & 7.66 & .968 & -.137 \\
Freshness & 6.16 & 7.82 & .966 & .102 \\
Assortment & 5.50 & 8.17 & .947 & -.038 \\
Kindness personnel & 6.09 & 7.92 & .832 & -.017 \\
Special offers & 7.08 & 7.89 & .287 & .911 \\
Prices & 7.09 & 8.11 & -.434 & .830 \\
\hline
\end{tabular}

* All store dimensions are measured on a 10-point scale (1=lowest, 10=highest).

** $\quad$ Each supermarket is rated on each dimension by 8000 households through exit interviews;

The mean rate reflects the average value over twenty super market chains. 


\section{ACKNOWLEDGEMENTS}

The paper is part of the first author's dissertation. A major part of the research has been conducted at Tilburg University and the Vrije Universiteit Amsterdam. The authors thank

GfK Panel Services for providing the data. They thank Els Gijsbrechts, Marnik Dekimpe, and Richard Paap for useful comments on a previous version. 


\section{REFERENCES}

ACNielsen (2002). ACNielsen Consumer Insight Magazine, 02(02).

Baumeister, R. F., \& Leary, M.R. (1995). The need to belong: Desire for interpersonal attachments as a fundamental human motivation. Psychological Bulletin, 117 (3), 497529.

Bawa, K. and R.W. Shoemaker (1987). The effects of a direct mail coupon on brand choice behavior. Journal of Marketing Research, 24 (4), 370-376.

Bell, D. R., \& Lal, R. (2003). The impact of frequent shopper programs in grocery retailing. Quantitative Marketing and Economics, 1 (2), 179-202.

Bell, D. R., \& Lattin, J.M. (1998). Shopping behavior and consumer preference for store price format: Why "large basket" shoppers prefer EDLP. Marketing Science, 17 (1), 66-88.

Berger, P. D., Bolton, R.N., Bowman D., Briggs E., Kumar, V., Parasuraman, A., \& Creed, T. (2002). Marketing actions and the value of customer assets: A framework for customer asset management. Journal of Service Research, 5 (1), 39-54.

Bhattacharya, C.B., Rao, H., \& Glynn, M.A. (1995). Understanding the bond of identification: An investigation of its correlates among art museum members. Journal of Marketing, 59 (4), 46-57.

Bhattacharya, C.B. \& Sen S. (2003). Consumer-company identification: A framework for understanding consumers' relationships with companies. Journal of Marketing, 67 (2), 76-88.

Bolton, R.N., Kannan, P.K., \& Bramlett, M.D. (2000). Implications of loyalty program membership and service experiences for customer retention and value. Journal of the Academy of Marketing Science, 28 (1), 95-108.

Bolton, R.N., Lemon K.N., \& Verhoef, P.C. (2004). The theoretical underpinnings of customer asset management: A framework and propositions for future research. Journal of the Academy of Marketing Science, 32 (3), 271-293.

Chamberlain, G. \& Griliches, Z. (1975). Unobservables with a variance-components structure: Ability, schooling, and the success of brothers. International Economic Review, 16 (2), 422-449.

Chandon, P., Wansink, B., \& Laurent, G. (2000). A benefit congruency framework of sales promotion effectiveness. Journal of Marketing, 64 (4), 65-81.

Cioletti, J. (2001). Super marketing: Points of sale. Supermarket Business, 56 (5), 37.

Day, G.S. (2000). Managing marketing relationships. Journal of the Academy of Marketing Science, 28 (1), 24-30.

DeWulf, K., Odekerken-Schröder, G., \& Iacobucci, D. (2001). Investments in consumer relationships: A cross-country and cross-industry exploration. Journal of Marketing, 65 (4), 33-50.

Dick, A. S. \& Basu, K. (1994). Customer loyalty: Toward an integrated conceptual framework. Journal of the Academy of Marketing Science, 22 (2), 99-113.

Dick, A.S. \& Lord, K.R. (1998). The impact of membership fees on consumer attitude and choice. Psychology \& Marketing, 15 (1), 41-58.

Dowling, G. R. \& Uncles, M. (1997). Do customer loyalty programs really work? Sloan Management Review, 38 (4), 71-82.

Drèze, X. \& Hoch, S.J. (1998). Exploiting the installed base using cross-merchandising and category destination programs. International Journal of Research in Marketing, 15 (5), 459-71.

Edvardsson, B., Johnson, M.D., Gustafsson, A., \& Strandvik, T. (2000). The effects of satisfaction and loyalty on profits and growth: Products versus services. Total Quality Management, 11 (7), 917-27. 
Erdem, T. \& Keane, M.P (1996). Decision-making under uncertainty: Capturing dynamic brand choice processes in turbulent consumer goods markets. Marketing Science, 15 (1), $1-20$

Feinberg, F.M., Krishna, A., \& Zhang, Z.J. (2002). Do we care what others get? A behaviorist approach to targeted promotions. Journal of Marketing Research, 39 (3), 277-91.

Fournier, S. (1998). Consumers and their brands: Developing relationship theory in consumer research. Journal of Consumer Research, 24 (4), 343-73.

Franses, P.H. (2005). On the use of marketing models for policy simulation. Journal of Marketing Research , 42 (1), 4-14.

Gatignon, H. \& Vosgerau, J. (2006). Moderating effects: The myth of mean centering. INSEAD Working Paper, version April 2006.

Geyskens, I., Steenkamp, J.B.E.M., Scheer, L.K., \& Kumar, N. (1996). The effects of trust and interdependence on relationship commitment: A transatlantic study. International Journal of Research in Marketing, 13 (4), 303-17.

Gönül, F., \& Srinivasan, K. (1996). Estimating the impact of consumer expectations on purchase behavior: A dynamic structural model. Marketing Science, 15 (3), 262-279.

Greene, W.H. (2000). Econometric Analysis London: Prentice Hall International.

Hair, J.F. Jr., Black, W.C., Babin, B.J., Anderson, R.E., \& Tatham, R.L.(2006). Multivariate data analysis (6th ed.) Upper Saddle River, New Jersey: Pearson Prentice Hall.

Hanssens, D. M., Parsons, L.J., \& Schultz, R.L. (2001). Market response models: Econometric and time series analysis. Boston: Kluwer Academic Publishers.

Hsee, C.K., Yu, F., Zhang, J., \& Zhang, Y. (2003). Medium maximization. Journal of Consumer Research, 30 (1), 1-14.

Jain, D. C. \& Singh, S.S. (2002). Customer lifetime value research in marketing: A review and future directions. Journal of Interactive Marketing, 16 (2), 34-46.

Johnson, M.D., Gustafsson, A., Andreassen, T.W. Lervik, L., \& Cha, J. (2001). The evolution and future of national customer satisfaction index models. Journal of Economic Psychology, 22 (2), 217-45.

Kahn, B. \& McAlister, L. (1997). How do customers decide where to purchase groceries? Reading, Massachusetts: Addison, Wesley.

Kahn, B.E. \& Schmittlein, D.C. (1992). The relationship between purchases made on promotion and shopping trip behavior. Journal of Retailing, 68 (3), 294-315.

Kim, B., Shi, M. \& Srinivasan, K. (2001). Reward programs and tacit collusion. Marketing Science, 20 (2), 99-120.

Kivetz, R. \& Simonson, I. (2002a). Earning the right to indulge: Effort as a determinant of customer preferences towards frequency program rewards. Journal of Marketing Research, 39 (2), 155-70.

---- (2002b). The role of effort advantage in consumer response to loyalty programs: The idiosyncratic fit heuristic. Journal of Marketing Research, 40 (4), 454-459.

Klemperer, P. (1987). The competitiveness of markets with switching costs. Rand Journal of Economics, 18 (1), 138-50.

Kopalle, P.K. \& Neslin, S.A. (2003). The economic viability of frequency reward programs in a strategic competitive environment. Review of Marketing Science, 1 (1), 1-39.

Koslowsky, S. (1999). Reducing your risk: What's happening in retail database marketing. Direct Marketing, 61 (9), 40-42.

Kumar, V. \& Reinartz, D.R. (2005). Customer relationship management: A database approach. New York: Wiley.

Leeflang, P.S.H., Wittink, D.R., Wedel, M., \& Naert, P.A. (2000). Building models for marketing decisions Boston: Kluwer Academic Publishers. 
Leenheer, J. \& Bijmolt, T.H.A. (2003). The adoption and effectiveness of loyalty programs: The retailer's perspective. MSI working paper series, report 03-124.

Lewis, H.G. (1997). Does your "loyalty" program inspire any loyalty? Direct Marketing 59 (6), 46-48.

Lewis, M. (2004). The influence of loyalty programs and short-term promotions on customer retention. Journal of Marketing Research, 41(4), 281-292.

Liebermann, Y. (1999). Membership clubs as a tool for enhancing buyers' patronage. Journal of Business Research, 45 (3), 291-97.

Liston-Heyes, C. (2002). Pie in the sky? Real versus perceived values of air miles. Journal of Consumer Policy. 25 (1), 1-27.

Mägi, A.W. (2003). Share of wallet in retailing: The effects of customer satisfaction, loyalty cards and shopper characteristics. Journal of Retailing, 109 (2), 1-11.

Mauri, C. (2003). Card loyalty. A new emerging issue in grocery retailing. Journal of Retailing and Consumer Services, 10 (1), 13-25.

Mittal, B. (1994). An integrated framework for relating diverse consumer characteristics to supermarket coupon redemption. Journal of Marketing Research, 31 (4), 533-44.

Muniz, A.M. \& O'Guinn, T.C. (2001). Brand community. Journal of Consumer Research, 27 (4), 412-32.

Nakanishi, M. \& Cooper, L.C. (1982). Simplified estimation procedures for MCI models. Marketing Science, 1 (3), 314-20.

Noble, S. M. \& Phillips, J. (2004). Relationship hindrance: Why would consumers not want a relationship with a retailer? Journal of Retailing, 80(2), 289-303.

Nunes, J.C. \& Drèze X. (2006). Your loyalty program is betraying you. Harvard Business Review, 84 (April), 124-131.

Odin, Y., Odin, N., \& Valette-Florence, P. (2001). Conceptual and operational aspects of brand loyalty: an empirical investigation. Journal of Business Research, 53 (2), 75-84.

Oliver, R.L. (1999). Whence consumer loyalty?, Journal of Marketing, 63 (Special Issue), 3344.

Phelps, J., D'Souza, G., \& Nowak, G. (2001) Antecedents and consequences of consumer privacy concerns: An empirical investigation. Journal of Interactive Marketing, 15 (4), 2-17.

Phelps, J., Nowak, G., \& Ferrell, E. (2000). Privacy concerns and consumer willingness to provide personal information. Journal of Public Policy \& Marketing, 19 (1), 27-41.

Roehm, M. L., Pullins, E.B., \& Roehm Jr., H.A. (2002). Designing loyalty-building programs for packaged goods brands. Journal of Marketing Research, 39 (2), 202-13.

Rossi, P.E., McCulloch, R.E., \& Allenby, G.M. (1996) The value of purchase history data in target marketing. Marketing Science, 15 (4), 321-40.

Schindler, R.M. (1998). Consequences of perceiving oneself as responsible for obtaining a discount: Evidence for smart-shopper feelings. Journal of Consumer Psychology, 7 (4), 371-92.

Sharp, B. \& Sharp, A. (1997). Loyalty programs and their impact on repeat-purchase loyalty patterns. International Journal of Research in Marketing, 14 (5), 473-86.

Taylor, G.A. \& Neslin, S.A. (2005). The current and future sales impact of a retail frequency reward program. Journal of Retailing, 81 (4), 293-305.

Thomas, J.S. (2001). A methodology for linking customer acquisition to customer retention. Journal of Marketing Research, 38 (2), 262-68.

Van Dijk, A., Van Heerde, H.J., Leeflang, P.S.H., \& Wittink, D.R. (2004). Similarity-based spatial methods to estimate shelf space elasticities, Quantitative Marketing and Economics, 2 (September), 257-277. 
Van Heerde, H.J. \& Bijmolt, T.H.A. (2005). Decomposing the promotional revenue bump for loyalty program members versus nonmembers, Journal of Marketing Research, 42 (4), 443-457.

Van Osselaer, S.M.J., Alba, J.W., \& Manchanda, P. (2003). Irrelevant information and mediated intertemporal choice. Journal of Consumer Psychology, 14 (2), 257-274.

Von Wangenheim, F. \& Bayón, T. (2006), Effects of capacity-driven service experiences on customer usage levels: Why revenue management systems are due for change. MSI working paper series, report 06-103.

Verbeek, M. (2000). A guide to modern econometrics. Chichester: John Wiley \& Sons, LTD.

Wooldridge, J.M. (2002). Econometric analysis of cross section and panel data. Cambridge, Massachusetts: The MIT Press.

Yi, Y. \& Jeon, H. (2003). Effects of loyalty programs on value perception, program loyalty, and brand loyalty, Journal of the Academy of Marketing Science, 31 (3), 229-40.

Zhang, Z. J., Krishna, A. \& Dhar, S.K. (2000). The optimal choice of promotional vehicles: front-loaded or rear-loaded incentives, Management Science, 46 (3), 348-62. 


\section{Publications in the Report Series Research ${ }^{*}$ in Management}

\section{ERIM Research Program: "Marketing"}

\section{6}

The Effect of Feedback and Learning on DSS Evaluations

Ujwal Kayande, Arnaud de Bruyn, Gary Lilien, Arvind Rangaswamy and Gerrit Van Bruggen

ERS-2006-001-MKT

http://hdl.handle.net/1765/7302

Interaction Between Shelf Layout and Marketing Effectiveness and Its Impact On Optimizing Shelf Arrangements Erjen van Nierop, Dennis Fok and Philip Hans Franses

ERS-2006-013-MKT

http://hdl.handle.net/1765/7632

Institutional Forecasting: The Performance of Thin Virtual Stock Markets

Gerrit H. Van Bruggen, Martin Spann, Gary L. Lilien and Bernd Skiera

ERS-2006-028-MKT

http://hdl.handle.net/1765/7840

Irritation Due to Direct Mailings from Charities

Merel van Diepen, Bas Donkers and Philip Hans Franses

ERS-2006-029-MKT

http://hdl.handle.net/1765/7832

When Should Nintendo Launch its Wii? Insights From a Bivariate Successive Generation Model Philip Hans Franses and Carlos Hernández-Mireles

ERS-2006-032-MKT

http://hdl.handle.net/1765/7867

How Feedback Can Improve Managerial Evaluations of Model-based Marketing Decision Support Systems Ujwal Kayande, Arnaud de Bruyn, Gary Lilien, Arvind Rangaswamy and Gerrit van Bruggen

ERS-2006-039-MKT

http://hdl.handle.net/1765/7893

Moving in Social Circles - Social Circle Membership and Performance Implications

Willem Verbeke and Stefan Wuyts

ERS-2006-041-MKT

$\underline{\text { http://hdl.handle.net/1765/7899 }}$

Polysemy in Advertising

Stefano Puntoni, Jonathan E. Schroeder and Mark Ritson

ERS-2006-043-MKT

http://hdl.handle.net/1765/7898

Categorization by Groups

Rebecca W. Hamilton, Stefano Puntoni and Nader T. Tavassoli

ERS-2006-044-MKT

http://hdl.handle.net/1765/7900

Time-Series Models in Marketing

Marnik G. Dekimpe, Philip Hans Franses, Dominique M. Hansses and Prasad A. Naik

ERS-2006-049-MKT

$\underline{\text { http://hdl.handle.net/1765/7984 }}$

Dynamic and Competitive Effects of Direct Mailings

Merel van Diepen, Bas Donkers and Philip Hans Franses

ERS-2006-050-MKT

http://hdl.handle.net/1765/7948 
Multidimensional Scaling with Regional Restrictions for Facet Theory: An Application to Levi's Political Protest Data Patrick J.F. Groenen and Ivo A. van der Lans

ERS-2006-057-MKT

http://hdl.handle.net/1765/8045

The Quest for Citations: Drivers of Article Impact

Stefan Stremersch, Isabel Verniers and Peter C. Verhoef

ERS-2006-061-MKT

http://hdl.handle.net/1765/8127

"Emotional" versus "Emotioneel": Advertising Language and Emotional Appraisal

Stefano Puntoni

ERS-2006-066-MKT

http://hdl.handle.net/1765/8290

Do Loyalty Programs Really Enhance Behavioral Loyalty? An Empirical Analysis Accounting for Self-Selecting Members Jorna Leenheer, Harald J. van Heerde, Tammo H.A. Bijmolt and Ale Smidts

ERS-2006-076-MKT

* A complete overview of the ERIM Report Series Research in Management: https://ep.eur.nl/handle/1765/1

ERIM Research Programs:

LIS Business Processes, Logistics and Information Systems

ORG Organizing for Performance

MKT Marketing

F\&A Finance and Accounting

STR Strategy and Entrepreneurship 